\title{
MAGNETIC SUSCEPTIBILITY-BASED PROTEIN DETECTION USING MAGNETIC LEVITATION
}

\section{SUPPORTING INFORMATION}

\author{
Sena Yaman ${ }^{1}$ and H. Cumhur Tekin ${ }^{1,2 *}$ \\ ${ }^{1}$ Izmir Institute of Technology, Department of Bioengineering, 35430, Izmir, Turkey \\ ${ }^{2}$ METU MEMS Center, 06520, Ankara, Turkey \\ *Corresponding author: cumhurtekin@iyte.edu.tr
}

\section{Table of Contents}

Figure S1 | The photograph of the magnetic levitation platform ………................................ 3

Figure S2 | 3D drawing of the platform in the CAD software ............................................... 3

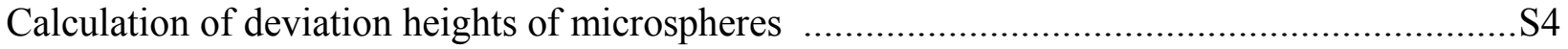

Table S1 | Investigation of measurement accuracy for deviation height determination .............S4

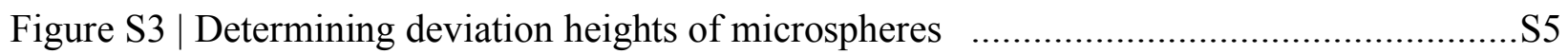

Biofunctionalization and levitation of particles for immunoglobulin $\mathrm{G}$ detection ....................S5

Figure S4 | Optimization of the anti-mouse IgG magnetic nanoparticles for detection experiments

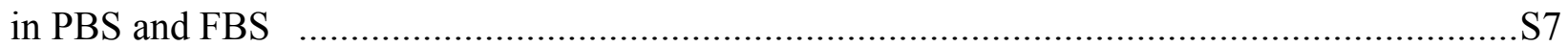

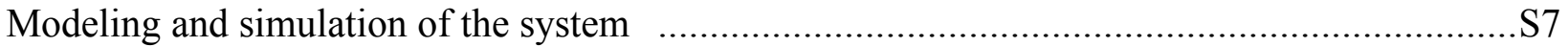

Figure S5 | Magnetic induction in y direction $\left(\mathrm{B}_{\mathrm{y}}\right)$ along the interspace between magnets at the

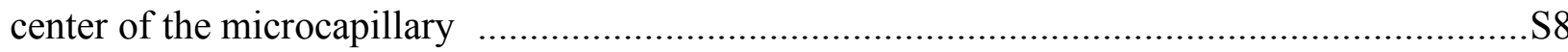

Figure S6 | The behavior of four different cases in the magnetic levitation setup ....................S9

Figure S7 | Simulation of assay sensitivity for binding of different particles onto polystyrene

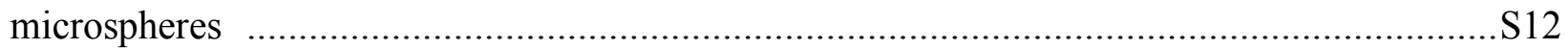

Levitation profile of s-PMS in paramagnetic medium .....................................................

Figure S8 | Levitation of s-PMS with s-MNP under different $\mathrm{Gd}^{3+}$ concentrations without b-

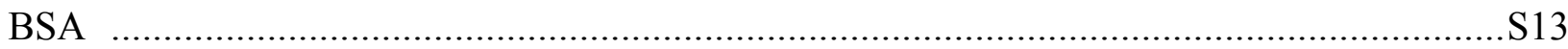

Figure S9 | Experimental data conducted in PBS samples for different b-BSA concentration

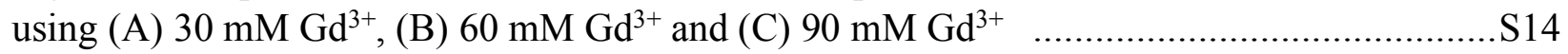


Fitting of experimental data S15

Figure S10 | The fitting of the experimental data for PBS-30 $\mathrm{mM} \mathrm{Gd}^{3+}$ experiments S15

Figure S11 | The bright-field and fluorescent micrographs of the microcapillary channel ......S16 Figure S12 | The deviation height of each microsphere under various b-BSA concentrations with PBST (A) and PBSP (B) dilutions, respectively S17

ROUT analysis for elimination of outlier microspheres ……........................................... 17

Figure S13 | Distribution analysis of FBS samples diluted with (A) PBST and (B) PBSP ......S18 Figure S14 | Distribution analysis of FBS samples diluted with (A) PBST and (B) PBSP after outliers were removed with ROUT analysis for $\mathrm{Q}=0.5 \%$ S18

Figure S15 | Distribution analysis of FBS samples diluted with (A) PBST and (B) PBSP after outliers were removed with ROUT analysis for $\mathrm{Q}=1 \%$

Figure S16 | Distribution analysis of FBS samples diluted with (A) PBST and (B) PBSP after outliers were removed with ROUT analysis for $\mathrm{Q}=2 \%$

Figure S17 | Distribution analysis of FBS samples diluted with (A) PBST and (B) PBSP after outliers were removed with ROUT analysis for $\mathrm{Q}=5 \%$ S20

Figure S18 | Distribution analysis of reference tests (i.e., $0 \mathrm{~g} / \mathrm{mL}$ b-BSA) in serum samples diluted with (A) PBST and (B) PBSP before and after removing outliers with ROUT for different Q S20

Figure S19 | The deviation height of each microsphere under various b-BSA concentrations when the outliers are removed using ROUT method with $\mathrm{Q}=1 \%$ for PBST (A) and PBSP (B) dilution, respectively S2 1

Figure S20 | Levitation profile of s-PMS in the absence and presence of b-BSA diluted in PBSP under $30 \mathrm{mM} \mathrm{Gd}^{3+}$ concentration S21

Figure S21 | Experimental data conducted in FBS samples for different b-BSA concentration using $30 \mathrm{mM} \mathrm{Gd}^{3+}$ S22

Figure S22 | Experimental data conducted in FBS samples for different b-BSA concentration using $30 \mathrm{mM} \mathrm{Gd}^{3+}$ and 1:10 diluted s-PMS S23

Figure S23 | Deviation height analysis of the anti-mouse IgG microspheres for different concentrations of mouse IgG spiked in (A) PBS and (B) FBS ............................................ 223

Table S2 | Summary of the magnetic levitation-based protein detection strategies S24

Figure S24 | Comparison of deviation heights of s-PMS in the presence of $1 \mathrm{ng} / \mathrm{mL}$ b-BSA under two different incubation protocols using $30 \mathrm{mM} \mathrm{Gd}^{3+}$ in PBS. ........................................... 224

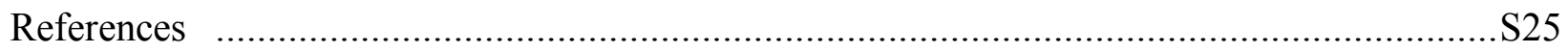




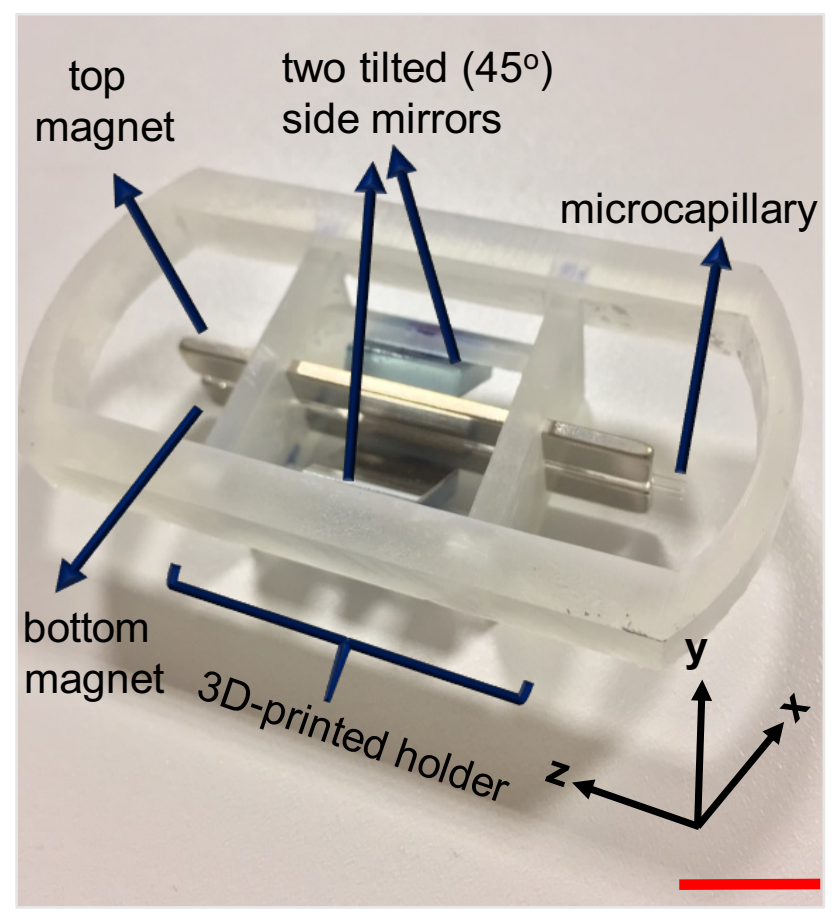

Figure S1 The photograph of the magnetic levitation platform. The three main components: (i) top and bottom magnets, (ii) glass microcapillary channel, and (iii) two side mirrors, which are assembled using a 3D-printed holder. Scale bar is $1 \mathrm{~cm}$.

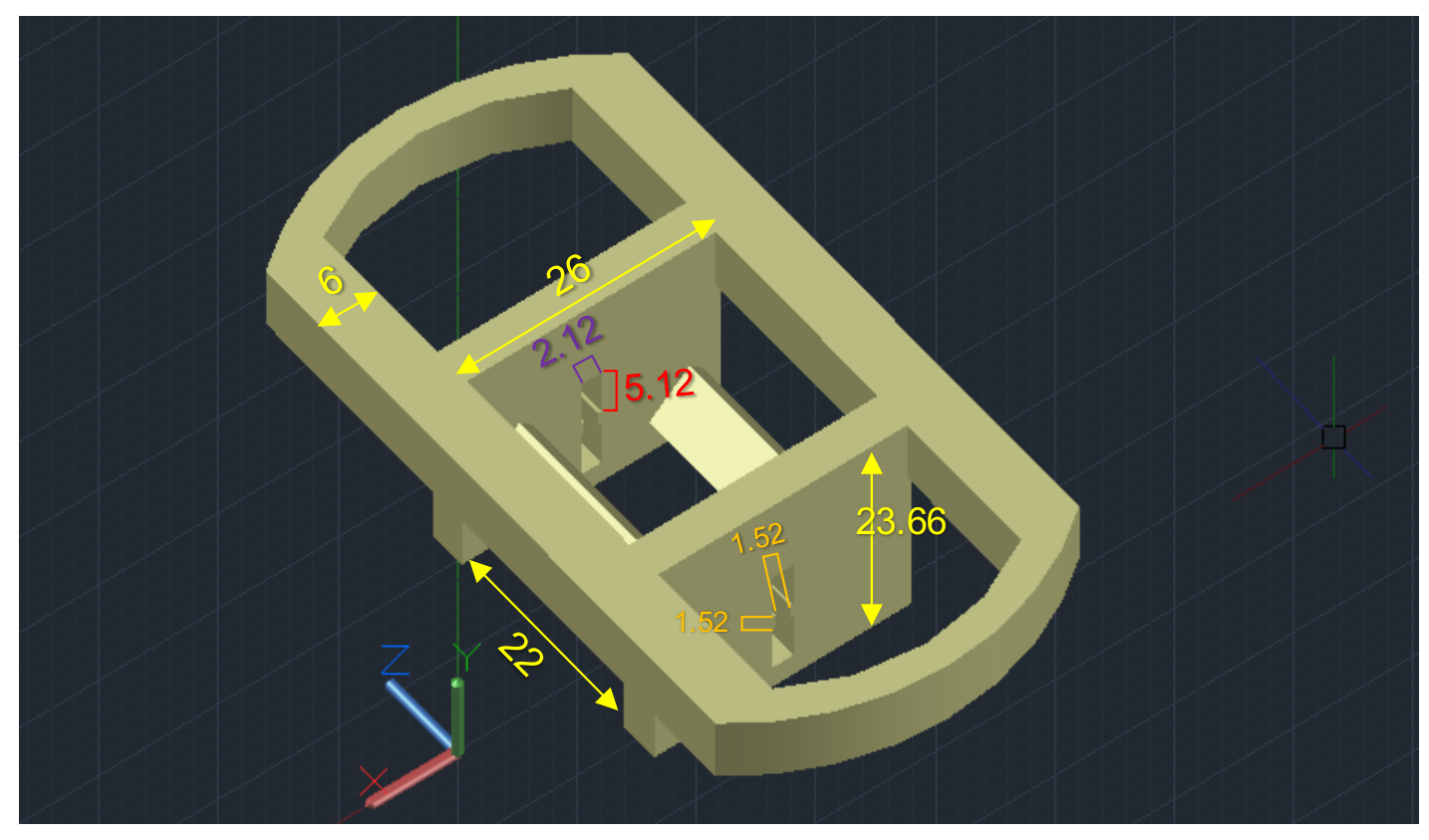

Figure S2 3D drawing of the platform in the CAD software. The lengths are in -mm scale. 


\section{Calculation of deviation heights of microspheres}

Since channel heights and wall thicknesses of capillaries can be varying from capillary to capillary, capillary channels cannot be positioned to the exactly same place between the magnets in each experiment. Hence, microsphere positions from the centerline of the magnets were calculated for robust measurements. In this context, first, a reference image focusing the magnets was taken at the beginning of each levitation experiment and the observable top and bottom magnet thicknesses (T1, B1) were measured (Figure S3A). The centerline plane position between magnets (M1) was determined by taking the half of the distance between the top and bottom magnets (Figure S3A). During the tests, images of the microspheres in the microcapillary channel were obtained by focusing on the microspheres. (Figure S3B). Then, the position of the microspheres from the bottom of the image (H1) were measured. The height of the centerline plane from the bottom of the image was calculated by $\mathrm{M} 1+\mathrm{B} 1$. The deviation heights $\left(\mathrm{h}_{\mathrm{D}}\right)$ of the microspheres were calculated by subtracting the position of microspheres from the height of centerline plane $(\mathrm{D} 1=\mathrm{M} 1+\mathrm{B} 1-\mathrm{H} 1)$. With this method, deviation heights of $6 \mu \mathrm{m}$ diameter microspheres were determined accurately with a standard deviation less than $10.3 \mu \mathrm{m}$ (Table S1). Distance measurements on the images were conducted using Image J Software.

Table S1. Investigation of measurement accuracy for deviation height determination

\begin{tabular}{|c|c|c|c|}
\hline & \multicolumn{3}{|c|}{ Deviation Height $(\boldsymbol{\mu m})$} \\
\hline \# of measurement & $\mathbf{1}^{\text {st }} \mathbf{b e a d}$ & $\mathbf{2}^{\text {nd }}$ bead & $\mathbf{3}^{\text {rd }}$ bead \\
\hline $\mathbf{1}$ & 225.68 & 192.53 & 172.29 \\
\hline $\mathbf{2}$ & 249.64 & 196.32 & 175.93 \\
\hline $\mathbf{3}$ & 224.28 & 189.48 & 183.58 \\
\hline $\mathbf{4}$ & 223.7 & 186.42 & 181.66 \\
\hline $\mathbf{5}$ & 224.46 & 189.84 & 183.72 \\
\hline $\mathbf{6}$ & 224.87 & 186.94 & 181.59 \\
\hline & $\mathrm{SD}= \pm 10.24 \mu \mathrm{m}$ & $\mathrm{SD}= \pm 3.67 \mu \mathrm{m}$ & $\mathrm{SD}= \pm 4.64 \mu \mathrm{m}$ \\
\hline
\end{tabular}



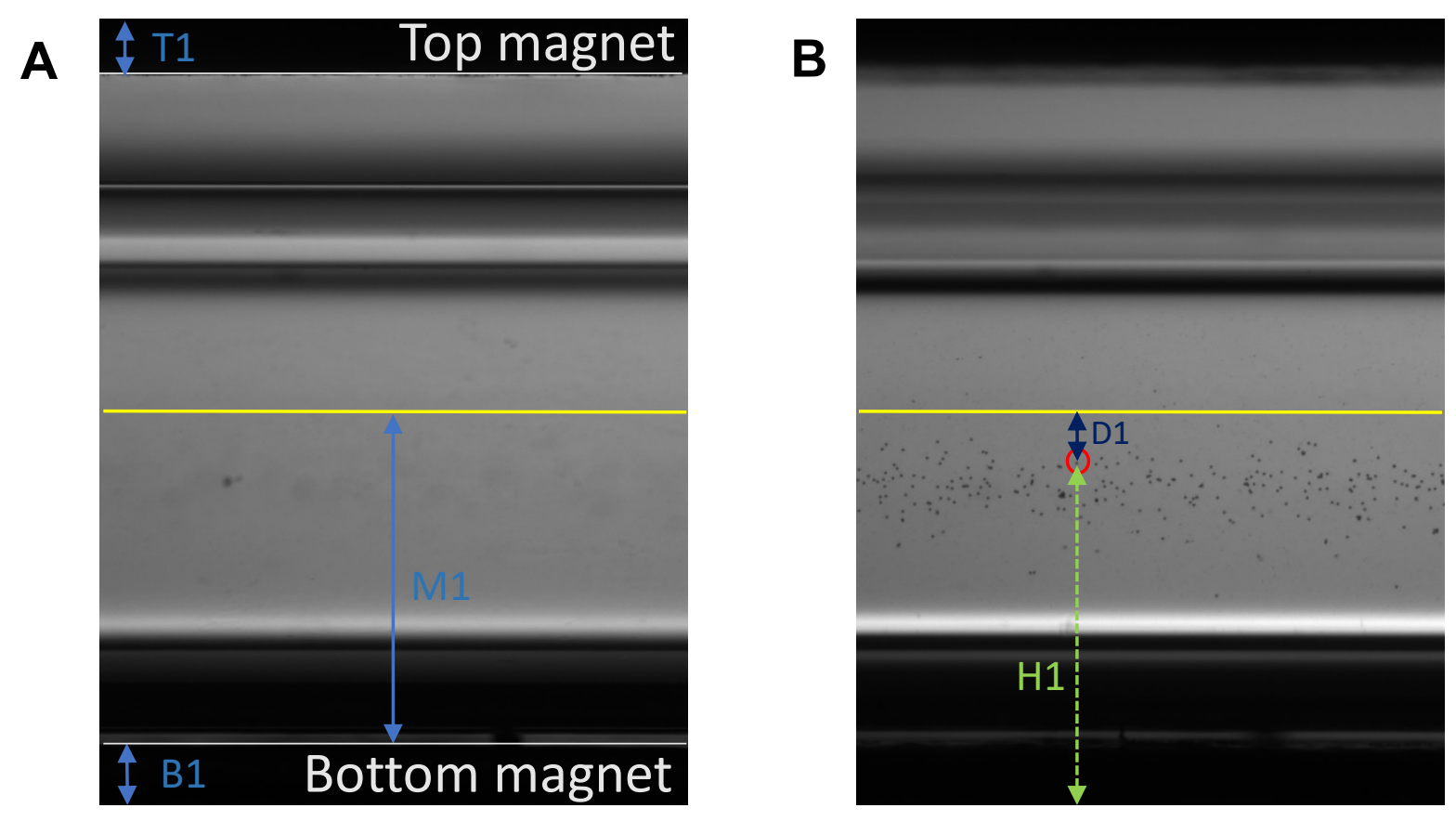

Figure S3 Determining deviation heights of microspheres. Micrographs optically focused on (A) magnets and (B) microspheres. Yellow line: centerline plane, T1, B1: the observable of top and bottom magnet thicknesses, M1: the distance of centerline plane to the top surface of the bottom magnet (half of the distance between two magnets, which is equal to (Image height-(T1+B1))/2), H1: height of the microsphere measured from the bottom of the image, and D1: deviation height of the microsphere.

\section{Biofunctionalization and levitation of particles for immunoglobulin $\mathbf{G}$ detection}

Biofunctionalization of streptavidin microspheres and magnetic nanoparticles was achieved by coupling biotinylated $\mathrm{Ab}$ onto the bead surfaces via streptavidin-biotin interaction. In this regard, both s-PMS and s-MNP were biofunctionalized with biotinylated goat anti-mouse IgG antibodies. First, $1 \mu \mathrm{L}$ stock solutions of s-PMS and s-MNP were dissolved in a dilution buffer ( Buffer 1: PBS containing 1\% (w/v) of Pluronic (PBSP) or Buffer 2: PBS containing 1\% (w/v) Pluronic and BSA (PBSP-BSA) ) in separate Eppendorf tubes. $1 \mu \mathrm{L}$ and $0.08 \mu \mathrm{L}$ of biotinylated anti-mouse IgG antibodies $(0.5 \mathrm{mg} / \mathrm{mL})$ were added to s-PMS and s-MNP, respectively. The solution volume in each Eppendorf tube was completed to $100 \mu \mathrm{L}$ with the dilution buffer. The Eppendorf tubes were agitated during $30 \mathrm{~min}$ on a vortex. Then, the non-occupied streptavidin molecules on the beads were blocked with biotin to avoid non-specific interactions. $1 \mu \mathrm{L}$ and $0.08 \mu \mathrm{L}$ of $1 \mathrm{mg} / \mathrm{mL}$ biotin 
solution were added to the tubes for s-PMS and s-MNP, respectively. After 30 min of mixing with biotin, both microspheres and magnetic nanoparticles were centrifugated and washed twice using dilution buffer. Lastly, microspheres and magnetic nanoparticles were resuspended in the dilution buffer at their initial stock concentration.

For IgG detection experiments, the microspheres were added to into the dilution buffer at a concentration of $10^{6}$ particles per $\mathrm{mL}$. The sample solution $(200 \mu \mathrm{L})$ for both PBS and FBS experiments were diluted 1:1 using the dilution buffer and incubated with anti-mouse IgG microspheres for $30 \mathrm{~min}$. Then, the solution is centrifugated and resuspended in $200 \mu \mathrm{L}$ of dilution buffer. Anti-mouse $\operatorname{IgG}$ magnetic nanoparticles $(1 \mu \mathrm{L} / 3 \mu \mathrm{L})$ were added to the solution and incubated for $15 \mathrm{~min}$. Later, the solution is mixed with $1 \mathrm{M}$ Gadolinium solution having a volume of $1.2 \mu \mathrm{L}$ to achieve $30 \mathrm{mM} \mathrm{Gd}^{3+}$ in the final loading solution of $40 \mu \mathrm{L}$.

Two different dilution buffers were tested to dilute sample solution for IgG experiments. These buffers were also used in biofunctionalization and levitation of particles as described previously. Buffer 1 (PBSP) resulted in microsphere aggregation for negative test in PBS containing $0 \mathrm{~g} / \mathrm{mL}$ mouse IgG. Most of microspheres were attracted at the bottom of the capillary channel during levitation procedure. This indicated non-specific binding on microspheres. In Buffer 2 (PBSPBSA), BSA molecules were added into the Buffer 1 at $1 \%(w / v)$ to block the surfaces and eliminate non-specific binding. By using this buffer, functionalized microspheres could be levitated with a $\mathrm{CV}(\%)$ of $6.7 \pm 0.4$ in PBS containing $0 \mathrm{~g} / \mathrm{mL}$ mouse IgG. Therefore, Buffer 2 was decided to be used in the experiments.

The amount of anti-mouse IgG magnetic nanoparticle was also tested to find suitable amount for sensitive detection of IgG. This approach was tested in PBS and FBS samples by comparing the deviation height differences between the reference $(0 \mathrm{~g} / \mathrm{mL} \operatorname{IgG})$ and $1 \mu \mathrm{g} / \mathrm{mL} \operatorname{IgG}$ concentration. $1 \mu \mathrm{L}$ magnetic nanoparticle concentration did not create a significant change in deviation height of microspheres compared to reference for PBS sample. Increasing magnetic nanoparticle concentration from $1 \mu \mathrm{L}$ to $3 \mu \mathrm{L}$ increased the deviation height difference between the reference and $1 \mu \mathrm{g} / \mathrm{mL}$ IgG (Figure S4). For FBS sample, $3 \mu \mathrm{L}$ still gave significant change in the deviation heights. 


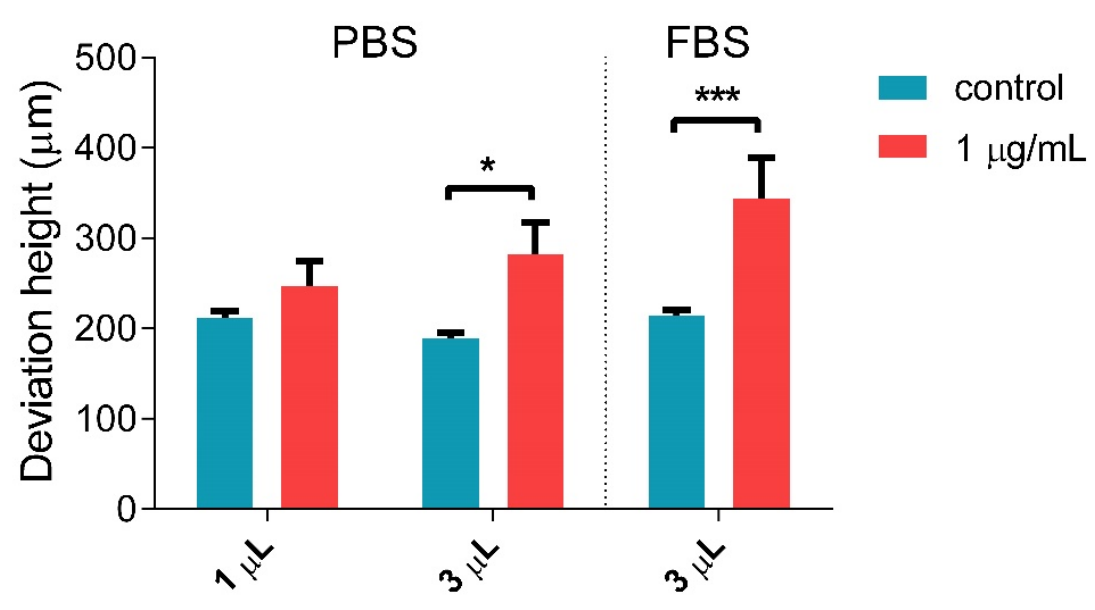

Anti-mouse IgG magnetic nanoparticles

Figure S4 Optimization of the anti-mouse IgG magnetic nanoparticles for detection experiments in $\mathrm{PBS}$ and $\mathrm{FBS} . *$ and $* * *$ represent $\mathrm{P}<0.05$ and $\mathrm{P}<0.001$, respectively.

\section{Modeling and simulation of the system}

Magnetic induction $(\vec{B})$ values generated by two N52 grade NdFeB magnets with a magnetization value of $1150 \mathrm{kA} \cdot \mathrm{m}^{-1}$ was estimated by finite element modeling (Figure 1B). Microspheres are focused in the middle of the magnet in $\mathrm{x}$ direction (Figure 1B) since the gravitational force is acting in y direction. Hence, microsphere levitation occurs in y-axis, where the magnetic force $\left(\vec{F}_{M}\right)$ is counterbalanced with the buoyancy force $\left(\vec{F}_{B}\right)$ :

$$
\begin{gathered}
\vec{F}_{M}+\vec{F}_{B}=0 \\
\frac{V \cdot\left(\chi_{p}-\chi_{m}\right)}{\mu_{0}}(\vec{B} \cdot \nabla) \vec{B}+V\left(\rho_{P}-\rho_{M}\right) \vec{g}=0
\end{gathered}
$$

, where $V$ is the volume of the microsphere, $\chi_{p}$ and $\chi_{m}$ are the magnetic susceptibilities of microsphere and surrounding medium (unitless), $\mu_{0}$ is the magnetic permeability of free space $\left(1.2566 \times 10^{-6} \mathrm{~kg} \cdot \mathrm{m} . \mathrm{A}^{-2} \cdot \mathrm{s}^{-2}\right), B$ is the magnetic induction (Tesla, T), $\nabla$ is the del operator, $\rho_{P}$ and $\rho_{M}$ are the volumetric density of microsphere and surrounding medium, and $g$ is the gravitational 
acceleration $\left(9.8 \mathrm{~m} \cdot \mathrm{s}^{-2}\right)$. The magnetic induction terms in equation 2 was calculated in y-direction as follows:

$$
(\vec{B} . \nabla) \vec{B}=\vec{B} x \frac{\partial \vec{B} y}{\partial x}+\vec{B} y \frac{\partial \vec{B} y}{\partial y}+\vec{B} z \frac{\partial \vec{B} y}{\partial z}
$$

Magnetic induction changes along z-axis was also neglected since the magnets are too long compared to its width. The change of magnetic induction along the interspace between the magnets is presented in Figure S5:

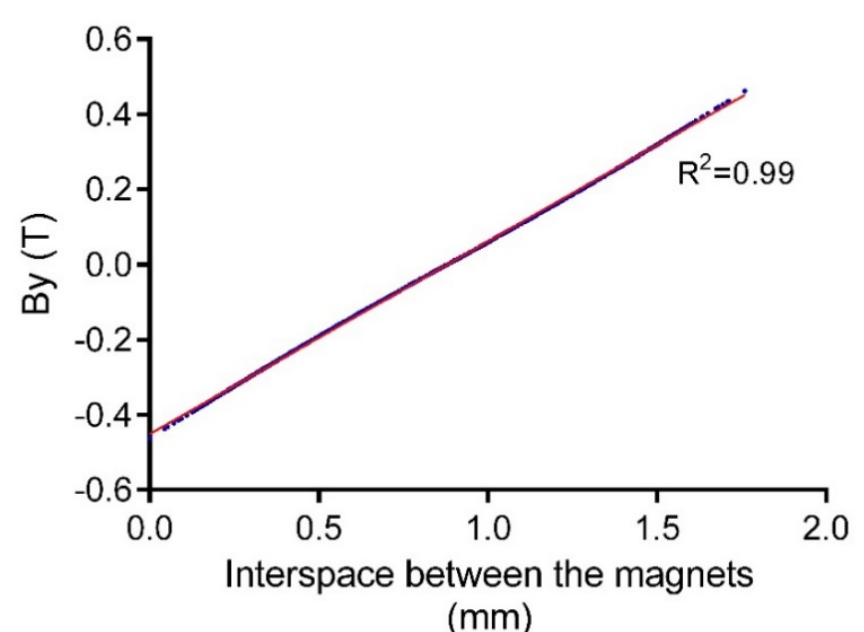

Figure S5 Magnetic induction in y direction $\left(B_{y}\right)$ along the interspace between magnets at the center of the microcapillary. The data (blue dots) obtained using a finite element modeling tool are fitted into linear curve (red line).

In the calculations, molar magnetic susceptibility of gadolinium-based paramagnetic medium and density of polystyrene microspheres were taken as $3.2 \times 10^{-4} \mathrm{M}^{-1}$ and $1.050 \mathrm{~g} / \mathrm{mL}$, respectively. ${ }^{1}$ Equilibrium positions of polystyrene microspheres were simulated with an in-house developed MATLAB program using equation 2 with the simulated $\vec{B}$. Magnetic susceptibility of microspheres loaded with magnetic nanoparticles was calculated by solving the equation 2 for $\chi_{p}$ using the $\vec{B}$ data at the levitation position of the microsphere along the channel height. The number 
of MNPs made the change in the magnetic susceptibility of the microspheres was then estimated with the calculated $\chi_{p}$. In the calculations, magnetic susceptibility of MNP and microspheres (without any MNPs) were taken as $1.4 \times 10^{-2}$ and 0 , respectively. ${ }^{2}$

In the levitation platform, the behavior of the diamagnetic microsphere with a density of 1.050 $\mathrm{g} / \mathrm{mL}$ and diameter of $6 \mu \mathrm{m}$ and $60 \mu \mathrm{m}$, and magnetic nanoparticle with a density of $1.800 \mathrm{~g} / \mathrm{mL}$ and diameter of $50 \mathrm{~nm}$ are shown in Figure S6. Magnetic nanoparticle is attracted by the magnet and gets no levitation under the applied magnetic field. On the other hand, magnetic levitation is achieved for the polymer microsphere and the microsphere is repelled by the magnets. In the presence of magnetic nanoparticle conjugation, the diamagnetic microsphere tends to levitate closer to the bottom magnet due to the increase in overall magnetic susceptibility. The levitation height is independent from the volume but depends on the density of the particle, as volume term $(V)$ can be cancelled out in equation 2 :

$$
\frac{\left(\chi_{p}-\chi_{m}\right)}{\mu_{0}}(\vec{B} . \nabla) \vec{B}+\left(\rho_{P}-\rho_{M}\right) \vec{g}=0
$$

Therefore, aggregated microspheres can levitate to the same height as single microspheres if their magnetic properties are the same as shown by the simulations in Figure S6.

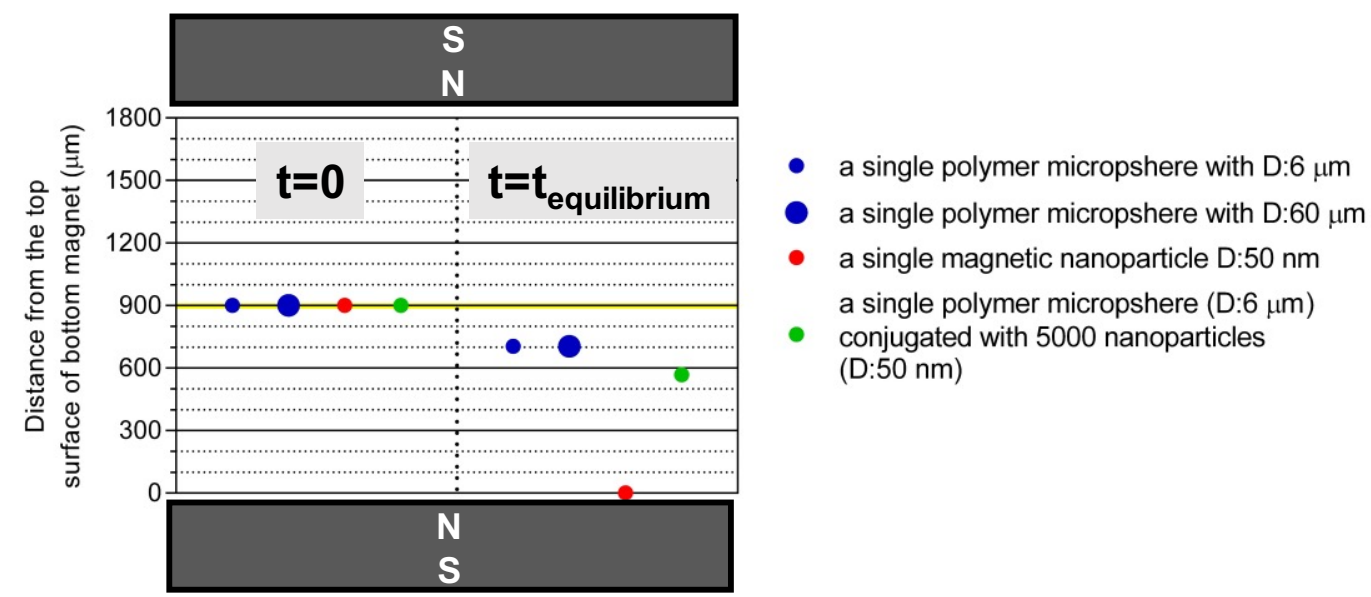

Figure S6 The behavior of four different cases in the magnetic levitation setup: (i) a single diamagnetic microsphere $(6 \mu \mathrm{m})$, (ii) a single polymer microsphere $(60 \mu \mathrm{m})$, (iii) a single magnetic nanoparticle $(50 \mathrm{~nm})$, and (iv) a single diamagnetic microsphere $(6 \mu \mathrm{m})$ conjugated with 5000 magnetic nanoparticles $(50 \mathrm{~nm})$. The graph shows initial $(\mathrm{t}=0)$ and final ( $\mathrm{t}=$ equilibrium) positions of the particles spiked in $30 \mathrm{mM} \mathrm{Gd}^{3+}$. Yellow line: centerline. 
For the reference condition (no b-BSA) diamagnetic microspheres (s-PMS) tend to migrate towards the centerline plane where magnetic field is minimum (Figure 1B) and become stationary where the magnetic force and the buoyancy force acting on those particles are equal to each other. For two particles having the same magnetic susceptibility, the particle with a higher density levitates closed to the lower magnet. On the centerline plane (i.e., the middle plane between top and bottom magnets), particles having nearly the same density as the levitation medium are gathered. Since s-PMS (i.e., $1.050 \mathrm{~g} / \mathrm{mL}$ ) is denser than the paramagnetic levitation medium (i.e., calculated as $\sim 1.016 \mathrm{~g} / \mathrm{mL}$ ), it levitates below the centerline (Figure S6).

We simulated the levitation of diamagnetic s-PMS to show the deviation height change of a single s-PMS in case of binding of three different particles in $\mathrm{Gd}^{3+}$ based paramagnetic levitation medium (Figure S7A): (i) diamagnetic nanoparticle with $50 \mathrm{~nm}$ diameter, $1.8 \mathrm{~g} / \mathrm{mL}$ density and 0 volumetric magnetic susceptibility, (ii) magnetic nanoparticles with $50 \mathrm{~nm}$ diameter, $1.8 \mathrm{~g} / \mathrm{mL}$ density and $1.4 \times 10^{-2}$ volumetric magnetic susceptibility, ${ }^{2}$ and (iii) b-BSA molecules with a $\sim 69.4$ $\mathrm{kDa}$ molecular weight and 0 volumetric magnetic susceptibility. According to the simulation results, the significant change in the deviation height of a s-PMS occurred in $30 \mathrm{mM} \mathrm{Gd}^{3+}$ due to magnetic nanoparticle attachment (Figure S7B). For example, the deviation height of s-PMS changed by $10.2 \%$ compared to the initial case (i.e., without magnetic nanoparticles) due to the attachment $10^{3}$ magnetic nanoparticles. On the other hand, $1.23 \%$ and $0.0034 \%$ changes were observed for $10^{3}$ diamagnetic nanoparticles and $10^{3} \mathrm{BSA}$ molecules, respectively. Hence, the change in the levitation height of microspheres are dominated by the magnetic susceptibility change of microspheres upon the binding of magnetic nanoparticles (Figure S6), which labels target molecules. The density changes on s-PMS due to binding of BSA and magnetic nanoparticle have only small influence on the s-PMS heights.

Simulations were also conducted to evaluate the deviation height of s-PMS with $10^{3}$ magnetic nanoparticles for different $\mathrm{Gd}^{3+}$ concentrations (Figure S7C). According to the results, increasing $\mathrm{Gd}^{3+}$ concentration decreases the deviation height change of s-PMS upon magnetic nanoparticle attachment. In other words, the lower the concentration of $\mathrm{Gd}^{3+}$ is, the higher the detection sensitivity is achieved. For example, the deviation height change for $90 \mathrm{mM} \mathrm{Gd}^{3+}$ is increased only by $5.5 \%$, whereas it is increased by $6.1 \%, 10.2 \%$ and $30.4 \%$ for $60 \mathrm{mM}, 30 \mathrm{mM}$ and $10 \mathrm{mM} \mathrm{Gd}^{3+}$, respectively due to the attachment of $10^{3}$ magnetic nanoparticles (Figure S7C). Even though 10 
$\mathrm{mM} \mathrm{Gd}^{3+}$ concentration gives the highest sensitivity in terms of deviation height change, s-PMSs come to the equilibrium at very close heights to the bottom of the capillary with a channel height of $1000 \mu \mathrm{m}$, which prevents observing them in the channel. Lastly, the change of a magnetic susceptibility and deviation height of s-PMS is simulated upon the attachment of magnetic nanoparticles at different numbers in $30 \mathrm{mM} \mathrm{Gd}^{3+}$ levitation medium (Figure S7D). Magnetic susceptibility values increase linearly with the number of the attached magnetic nanoparticles, whereas deviation height values increase sharply with the magnetic nanoparticles. With $30 \mathrm{mM}$ $\mathrm{Gd}^{3+}$, up to $\sim 4 \times 10^{-6}$ (SI units) magnetic susceptibility changes corresponding to $\sim 4 \times 10^{3}$ magnetic nanoparticle binding on the s-PMS can be observable in the capillary channel with a height of 1000 $\mu \mathrm{m} \pm 100 \mu \mathrm{m}$. 


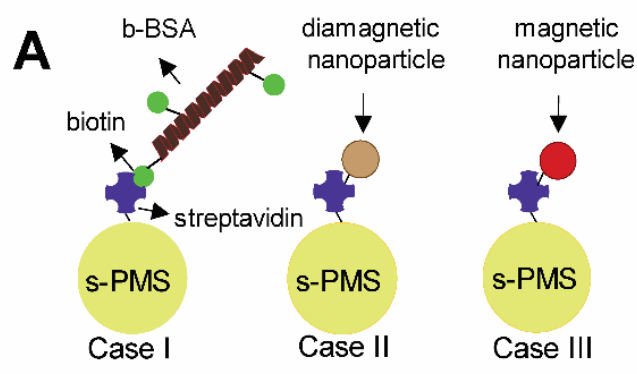

B
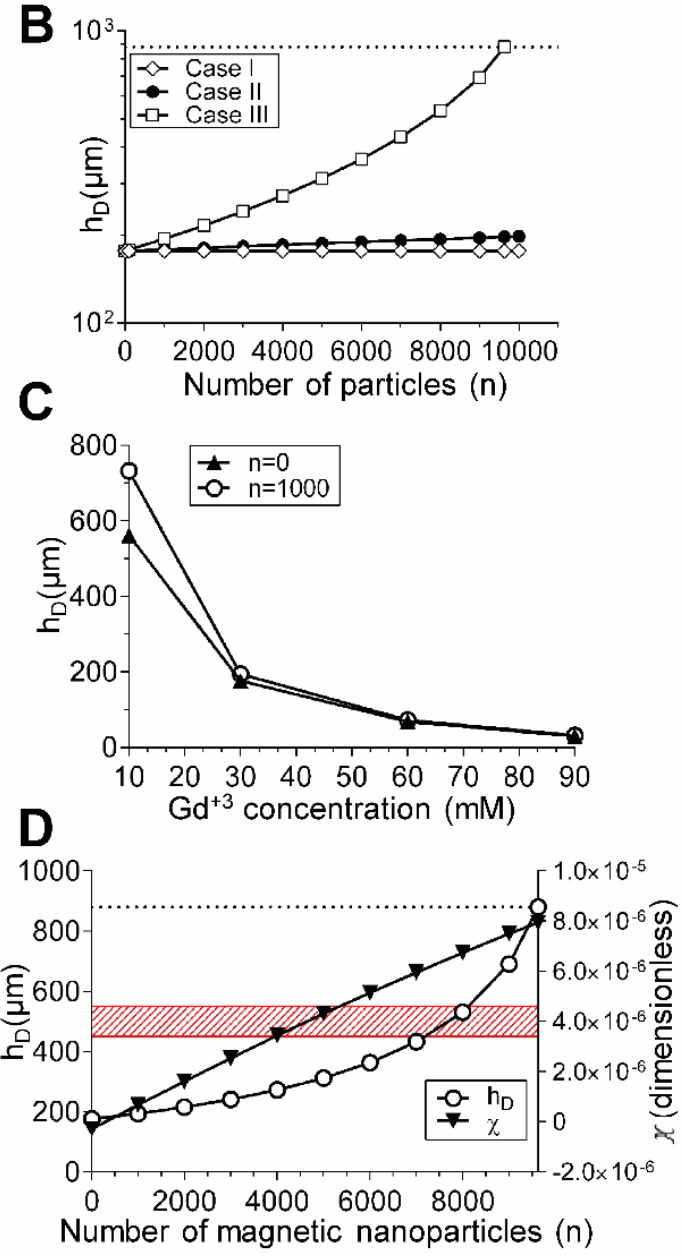

Figure S7 Simulation of assay sensitivity for binding of different particles onto polystyrene microspheres. (A) Schematic representation of the simulations. (B) Deviation heights of microspheres when covered with b-BSA molecules, magnetic nanoparticles, and diamagnetic nanoparticles at different numbers (n). Dashed line represents the top surface of the bottom of the magnet. The simulation is performed for $30 \mathrm{mM} \mathrm{Gd}^{3+}$-based paramagnetic medium. (C) Modeling of deviation heights of microspheres in case of binding of magnetic nanoparticles for $\mathrm{n}=0$ (control) and $\mathrm{n}=1000$ with $10 \mathrm{mM}, 30 \mathrm{mM}, 60 \mathrm{mM}$ and $90 \mathrm{mM} \mathrm{Gd}^{3+}$-based levitation medium. (D) Modeling of deviation heights of microspheres and the corresponding magnetic susceptibility in case of binding of magnetic nanoparticles at different numbers. Dashed line represents the top surface of the bottom of the magnet. Red shaded area is the range of microcapillary bottom surface distances $(450-550 \mu \mathrm{m})$ from the centerline. 


\section{Levitation profile of s-PMS in paramagnetic medium}

Sensitivity of magnetic levitation-based measurement can be adjusted by changing paramagnetic agent concentration as shown in the simulations (Figure S7). Different $\mathrm{Gd}^{3+}$ concentrations (i.e. 10, 30, 60 and $90 \mathrm{mM}$ ) were tested to levitate s-PMS with a diameter of $6 \mu \mathrm{m}$ suspended in PBS buffer with $1 \%(\mathrm{v} / \mathrm{v})$ of Tween ${ }^{\mathrm{TM}} 20$ surfactant during 30 min (Figure S8). As expected from simulation results (Figure S7C), s-PMS reached the bottom of the capillary channel $\left(\mathrm{h}_{\mathrm{D}}=500 \pm 50\right.$ $\mu \mathrm{m}$ ) for $10 \mathrm{mM} \mathrm{Gd}^{3+}$, which was not capable to levitate s-PMS in the channel and could not be used for protein detection experiments. Moreover, increasing the amount of $\mathrm{Gd}^{3+}$ resulted in levitating s-PMS at higher positions closed to the centerline plane, which was the middle plane between magnets. Microspheres reached their equilibrium levitation heights faster for higher $\mathrm{Gd}^{3+}$ concentrations (Figure S8B). For instance, deviation height values of s-PMS were remained constant after $25 \mathrm{~min}$ for $10 \mathrm{mM} \mathrm{Gd}^{3+}$, whereas this equilibrium was reached only after $10 \mathrm{~min}$ for $60 \mathrm{mM}$ of $\mathrm{Gd}^{3+}$. For protein detection experiments in different $\mathrm{Gd}^{3+}$ concentrations, the levitation could be conducted for $30 \mathrm{~min}$ to ensure steady-state deviation height profile.

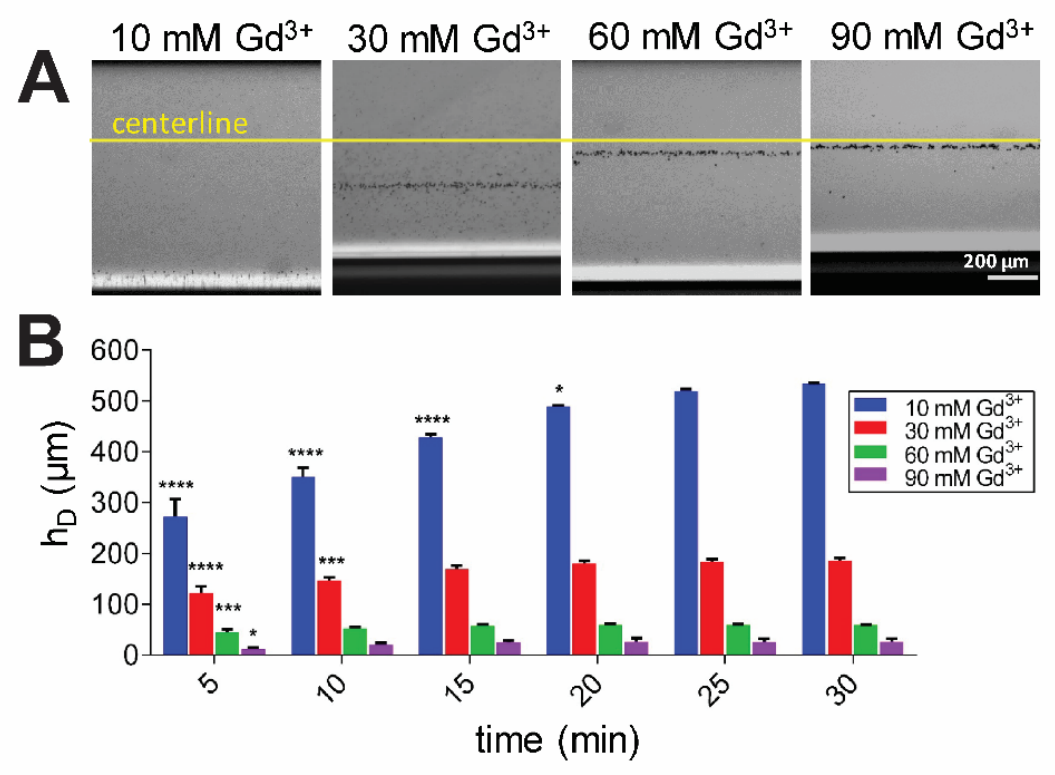

Figure S8 Levitation of s-PMS with s-MNP under different $\mathrm{Gd}^{3+}$ concentrations without b-BSA. (A) Micrographs of s-PMS, after 30 min levitation with 10, 30, 60 and $90 \mathrm{mM}$ of $\mathrm{Gd}^{3+}$. Yellow line represents centerline plane. (B) Deviation height analysis of microspheres. Data are shown as mean of three replicates with error bars $( \pm \mathrm{SD})$. Data for each $\mathrm{Gd}^{3+}$ concentration are compared with the final levitation value (i.e., the deviation profile after $30 \mathrm{~min}$ of levitation) at that concentration value using a one-way ANOVA. ****, ***, and * represent $\mathrm{P}<0.0001, \mathrm{P}<0.001$, and $\mathrm{P}<0.05$, respectively. 
A $\quad 30 \mathrm{mM} \mathrm{Gd}^{3+}$

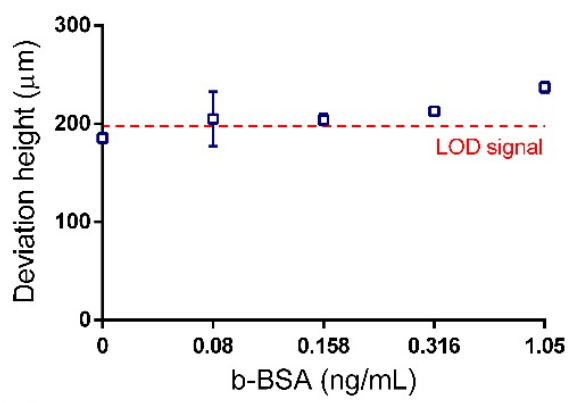

B $60 \mathrm{mM} \mathrm{Gd}^{3+}$
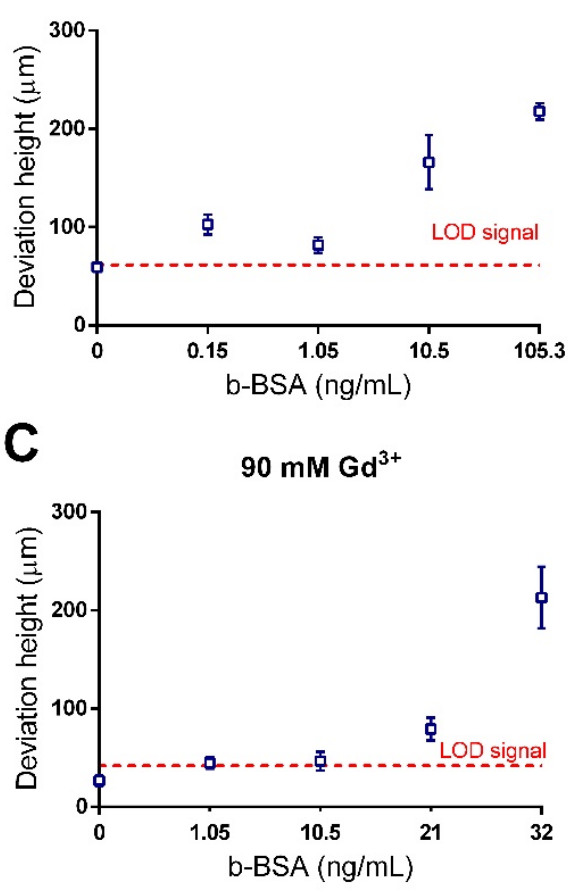

\begin{tabular}{|c|c|c|c|c|c|}
\hline $\begin{array}{c}\text { b-BSA } \\
(\mathbf{n g} / \mathbf{m L})\end{array}$ & $\begin{array}{c}\text { Average } \\
\text { height in } \\
\text { Test } 1(\boldsymbol{\mu m})\end{array}$ & $\begin{array}{c}\text { Average } \\
\text { height in } \\
\text { Test } \mathbf{2}(\boldsymbol{\mu m})\end{array}$ & $\begin{array}{c}\text { Average } \\
\text { height in } \\
\text { Test } \mathbf{3}(\boldsymbol{\mu m})\end{array}$ & $\begin{array}{c}\text { Average } \\
\text { height in all } \\
\text { tests }(\boldsymbol{\mu m})\end{array}$ & $\begin{array}{c}\mathbf{\pm} \text { SD } \\
(\boldsymbol{\mu m})\end{array}$ \\
\hline 0 & 179.8 & 189.4 & 186.9 & 185.4 & 4.1 \\
\hline 0.08 & 198.4 & 241.8 & 174.6 & 204.9 & 27.8 \\
\hline 0.158 & 210.4 & 204.8 & 196.9 & 204.1 & 5.5 \\
\hline 0.316 & 214.9 & 207.7 & 216.0 & 212.9 & 3.7 \\
\hline 1.05 & 230.1 & 239.6 & 242.0 & 237.2 & 5.2 \\
\hline
\end{tabular}

\begin{tabular}{|c|c|c|c|c|c|}
\hline $\begin{array}{c}\text { b-BSA } \\
(\mathbf{n g} / \mathbf{m L})\end{array}$ & $\begin{array}{c}\text { Average } \\
\text { height in } \\
\text { Test 1 }(\boldsymbol{\mu m})\end{array}$ & $\begin{array}{c}\text { Average } \\
\text { height in } \\
\text { Test 2 }(\boldsymbol{\mu m})\end{array}$ & $\begin{array}{c}\text { Average } \\
\text { height in } \\
\text { Test } \mathbf{3}(\boldsymbol{\mu m})\end{array}$ & $\begin{array}{c}\text { Average } \\
\text { height in all } \\
\text { tests }(\boldsymbol{\mu m})\end{array}$ & $\begin{array}{c}\mathbf{\pm} \text { SD } \\
(\boldsymbol{\mu m})\end{array}$ \\
\hline 0 & 58.8 & 60.2 & 58.7 & 59.2 & 0.7 \\
\hline 0.15 & 90.6 & 102.4 & 115.1 & 102.7 & 10.0 \\
\hline 1.05 & 70.6 & 89.6 & 84.8 & 81.6 & 8.1 \\
\hline 10.5 & 128.9 & 173.4 & 195.6 & 166.0 & 27.7 \\
\hline 105.3 & 229.2 & 210.1 & 214.4 & 217.9 & 8.2 \\
\hline
\end{tabular}

\begin{tabular}{|c|c|c|c|c|c|}
\hline $\begin{array}{c}\text { b-BSA } \\
(\mathbf{n g} / \mathrm{mL})\end{array}$ & $\begin{array}{c}\text { Average } \\
\text { height in } \\
\text { Test 1 }(\boldsymbol{\mu m})\end{array}$ & $\begin{array}{c}\text { Average } \\
\text { height in } \\
\text { Test 2 }(\boldsymbol{\mu m})\end{array}$ & $\begin{array}{c}\text { Average } \\
\text { height in } \\
\text { Test 3 }(\boldsymbol{\mu m})\end{array}$ & $\begin{array}{c}\text { Average } \\
\text { height in all } \\
\text { tests }(\boldsymbol{\mu m})\end{array}$ & $\begin{array}{c}\mathbf{\pm} \text { SD } \\
(\boldsymbol{\mu m})\end{array}$ \\
\hline 0 & 21.7 & 33.7 & 24.9 & 26.8 & 5.1 \\
\hline 1.05 & 43.7 & 52.3 & 38.3 & 44.8 & 5.7 \\
\hline 10.5 & 38.0 & 42.0 & 60.0 & 46.7 & 9.6 \\
\hline 21 & 66.4 & 77.0 & 94.5 & 79.3 & 11.6 \\
\hline 32 & 170.3 & 225.8 & 243.6 & 213.2 & 31.2 \\
\hline
\end{tabular}

Figure S9 Experimental data conducted in PBS samples for different b-BSA concentration using (A) $30 \mathrm{mM} \mathrm{Gd}^{3+}$, (B) $60 \mathrm{mM} \mathrm{Gd}^{3+}$ and (C) $90 \mathrm{mM} \mathrm{Gd}^{3+}$. 


\section{Fitting of experimental data}

Linear fitting of experimental data provided a sufficient coefficient of determination $\left(\mathrm{R}^{2}=0.92\right)$ compared to sigmoid and exponential fits presented in Figure S10. Since the linear regression is commonly preferred in bead-based assays and detection platforms, ${ }^{3,4,5}$ we preferred to use linear fits for the estimation of detectable protein concentrations. Lowest detected protein concentration values were calculated as the intersection of these linear curves. For a protein concentration above and near the LOD line of $30 \mathrm{mM} \mathrm{Gd}^{3+}$ (i.e., $158 \mathrm{pg} / \mathrm{mL}$ ), the deviation height was also statistically different $(\mathrm{p}<0.05)$ compared to the reference (Figure S10C).

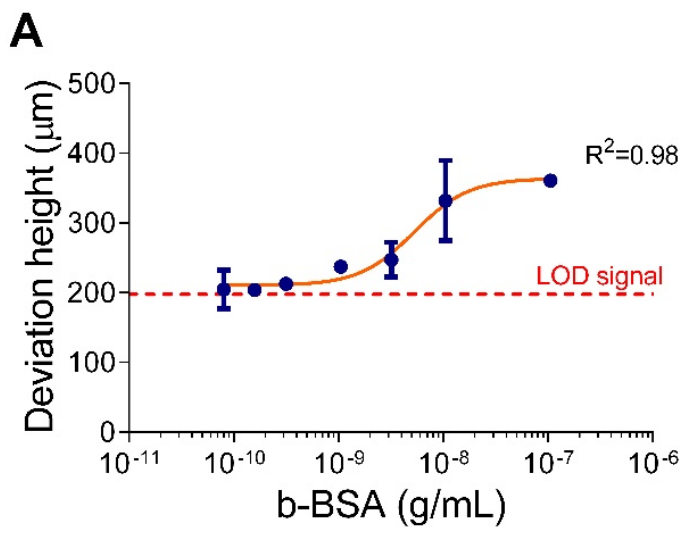

B
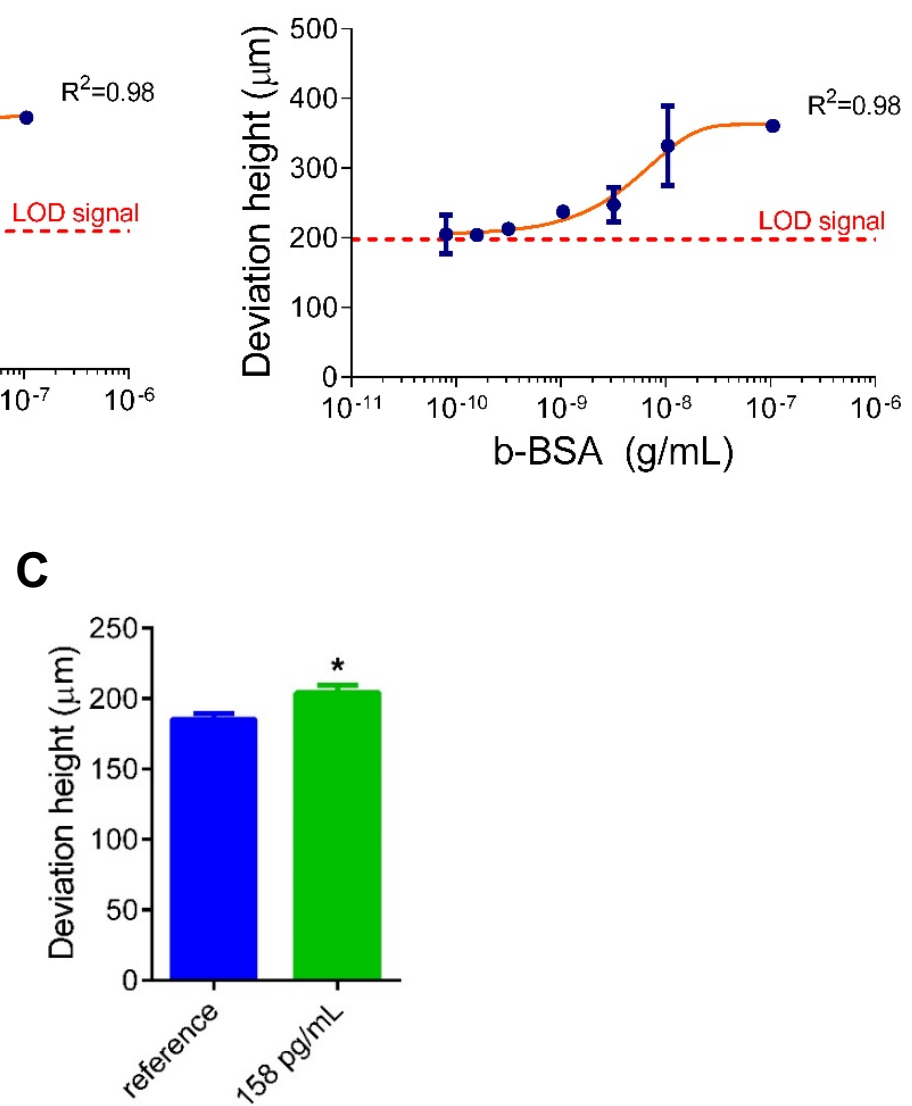

Figure S10 The fitting of the experimental data for PBS-30 $\mathrm{mM} \mathrm{Gd}^{3+}$ experiments using a (A) sigmoidal and an (B) exponential fit. LOD signals were calculated by adding $3 * \mathrm{SD}$ of the reference signal $(0 \mathrm{~g} / \mathrm{mL})$ to the mean of the reference signal. (C) A tested b-BSA concentration above and near the LOD line in PBS for $30 \mathrm{mM} \mathrm{Gd}^{3+}$ was also compared to the reference with an unpaired ttest with Welch's correction. Statistical significance $(*)$ was determined as $\mathrm{p}<0.05$. 


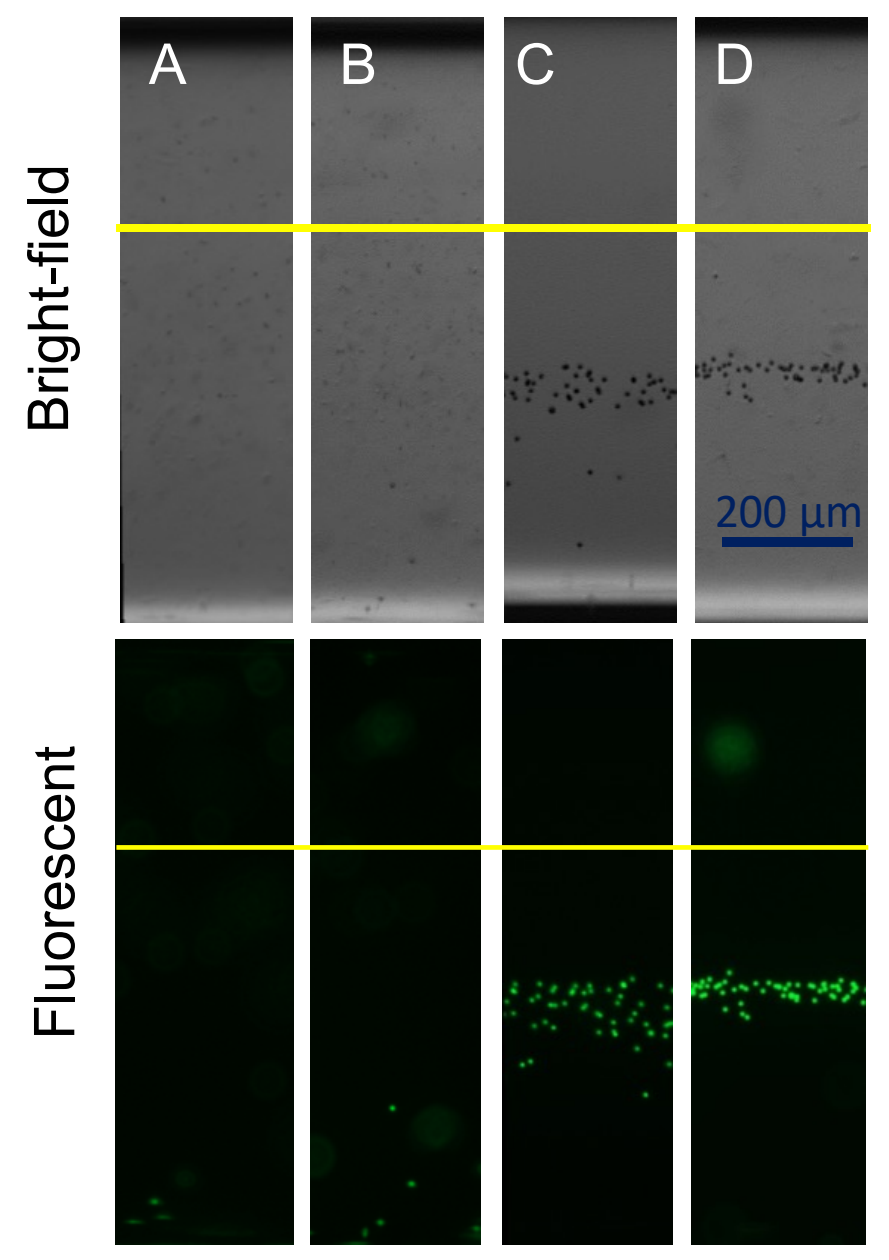

Figure S11 The bright-field and fluorescent micrographs of the microcapillary channel (A) without diluting the sample, (B) with diluting the sample 1:1 with PBST buffer (PBS containing $1 \%$ Tween $20(\mathrm{v} / \mathrm{v}))$, (C) with diluting the sample 1:10 with PBST buffer, and (D) with diluting the sample 1:1 with PBSP buffer (PBS containing 1\% Pluronic F-127 (w/v)). The sample contained dialyzed FBS without b-BSA. Experiments were conducted with $30 \mathrm{mM} \mathrm{Gd}^{+3}$-based levitation medium. Yellow line: centerline of the magnets. 


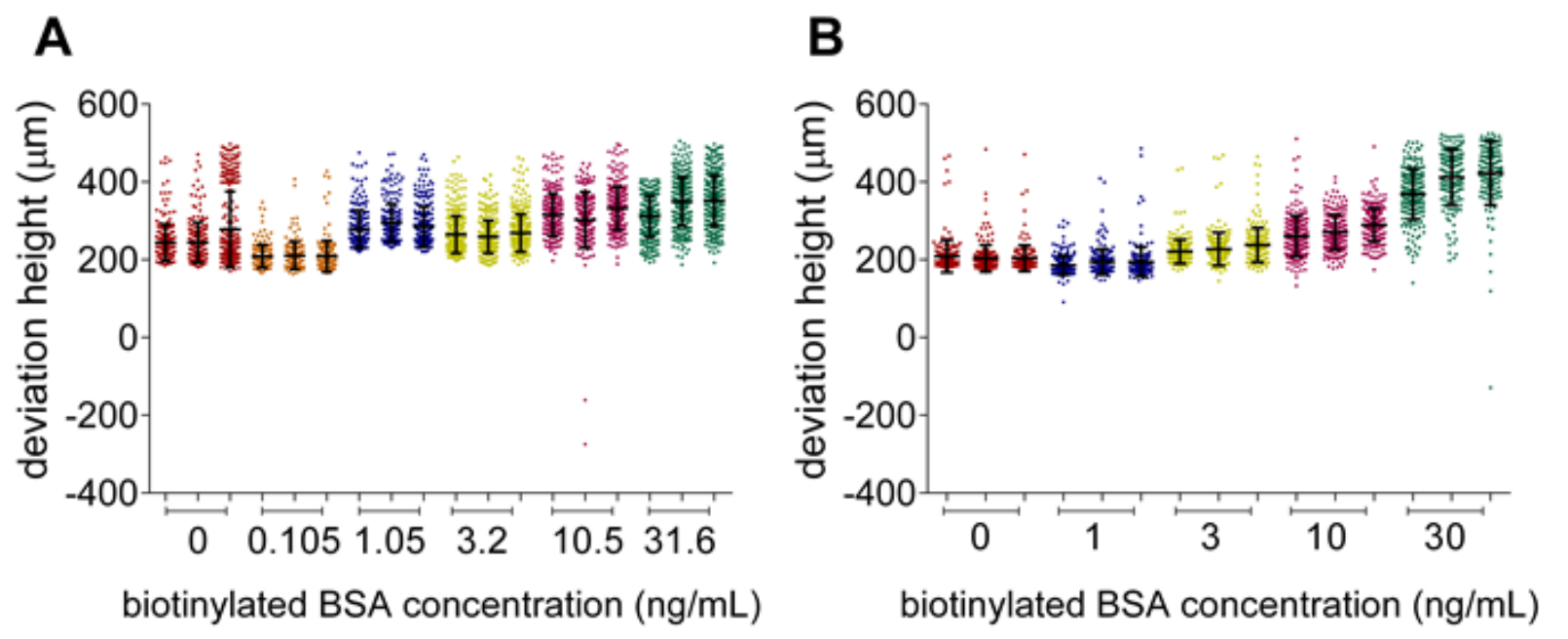

Figure S12 The deviation height of each microsphere under various b-BSA concentrations with PBST (A) and PBSP (B) dilutions, respectively.

\section{ROUT analysis for elimination of outlier microspheres}

$\mathrm{CV}$ values of reference tests with $0 \mathrm{~g} / \mathrm{mL}$ b-BSA were statistically not different even from high bBSA concentration (i.e. $30 \mathrm{ng} / \mathrm{mL}$ ) since there could be non-specific bindings on s-PMS surfaces in serum (Figure S13). In order to eliminate s-PMS distribution due to non-specific bindings, we statistically determined and removed outlier s-PMS using the ROUT Method. ${ }^{6}$ For different maximum desired false discovery rate $(\mathrm{Q})$ values (i.e. 0.5-5\%), CV values were calculated (Figure $\mathrm{S} 14-\mathrm{S} 17)$. With this method, CV values of reference tests became statistically different for various b-BSA concentrations. Furthermore, increased in $\mathrm{Q}$ value $(\mathrm{Q}>0.5 \%)$ did not affect $\mathrm{CV}$ values of reference tests (Figure S18). Since increasing Q more than 1 increases the risk of getting falsely identified outliers ${ }^{6}, \mathrm{CV}$ analyses were made with removing outliers under the ROUT method with $\mathrm{Q}=1 \%$ value. Experimental data after removing identifiers with $\mathrm{Q}=1$ for serum samples of $b$-BSA were also presented in Figure S19. 

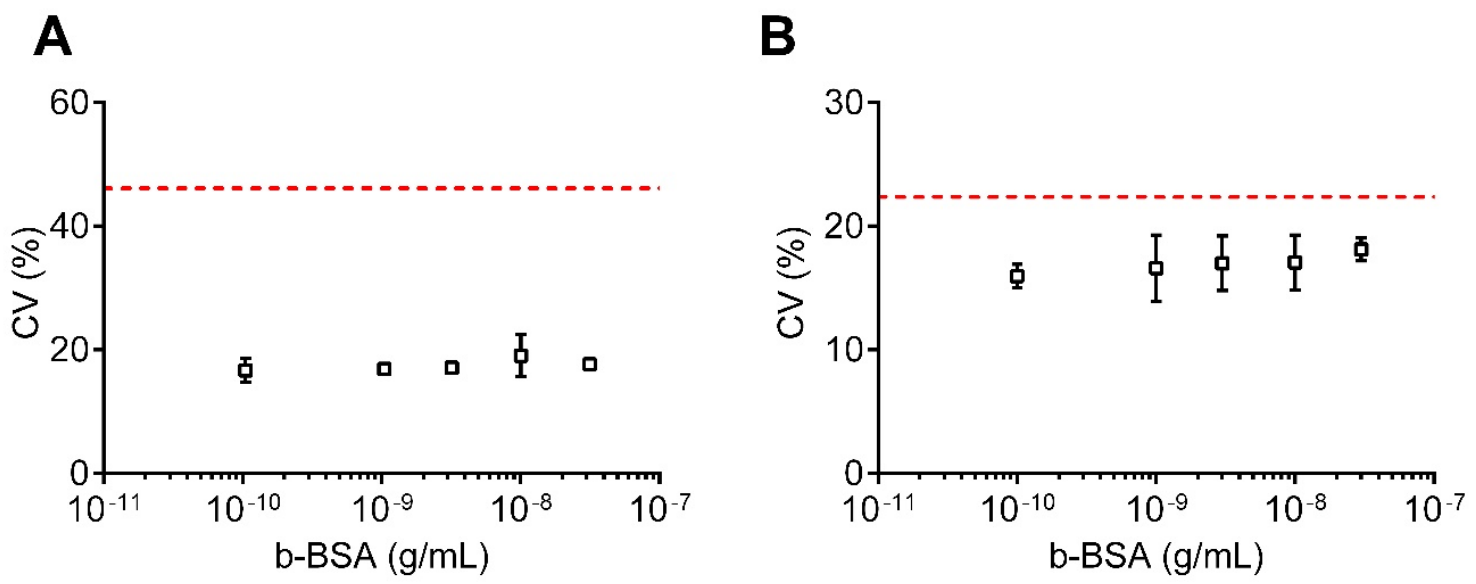

Figure S13 Distribution analysis of FBS samples diluted with (A) PBST and (B) PBSP. Data are presented as mean of three replicates with error bars $( \pm \mathrm{SD})$. Dashed lines represent LOD signal (LOD is calculated as mean $\mathrm{CV}(\%)$ of reference plus three times of $\pm \mathrm{SD})$. CV values of reference tests for PBST and PBSP were $25.2 \pm 7.0$ and $17.7 \pm 1.5$, respectively. $30 \mathrm{ng} / \mathrm{mL}$ data of both buffers were compared with reference using a t-test with Welch's correction and no significance was observed.
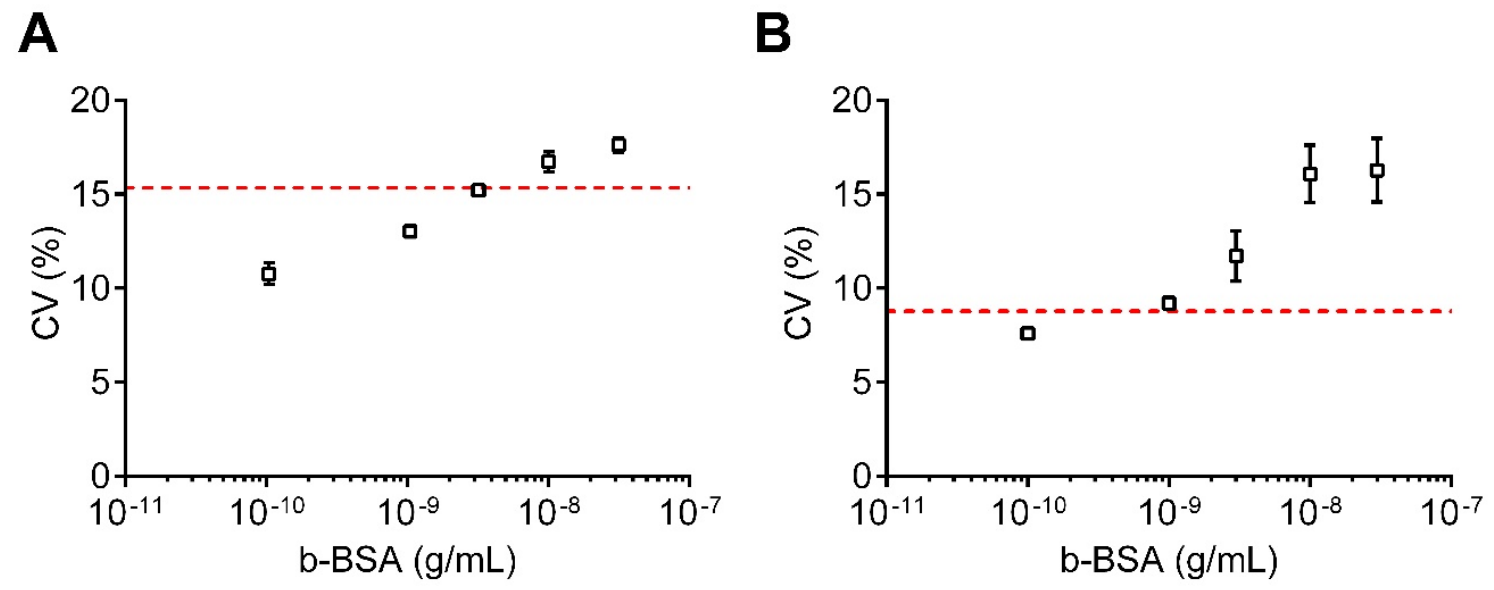

Figure S14 Distribution analysis of FBS samples diluted with (A) PBST and (B) PBSP after outliers were removed with ROUT analysis for $\mathrm{Q}=0.5 \%$. Data are presented as mean of three replicates with error bars $( \pm \mathrm{SD})$. Dashed lines represent LOD signal (LOD is calculated as mean $\mathrm{CV}(\%)$ of reference plus three times of $\pm \mathrm{SD})$. 

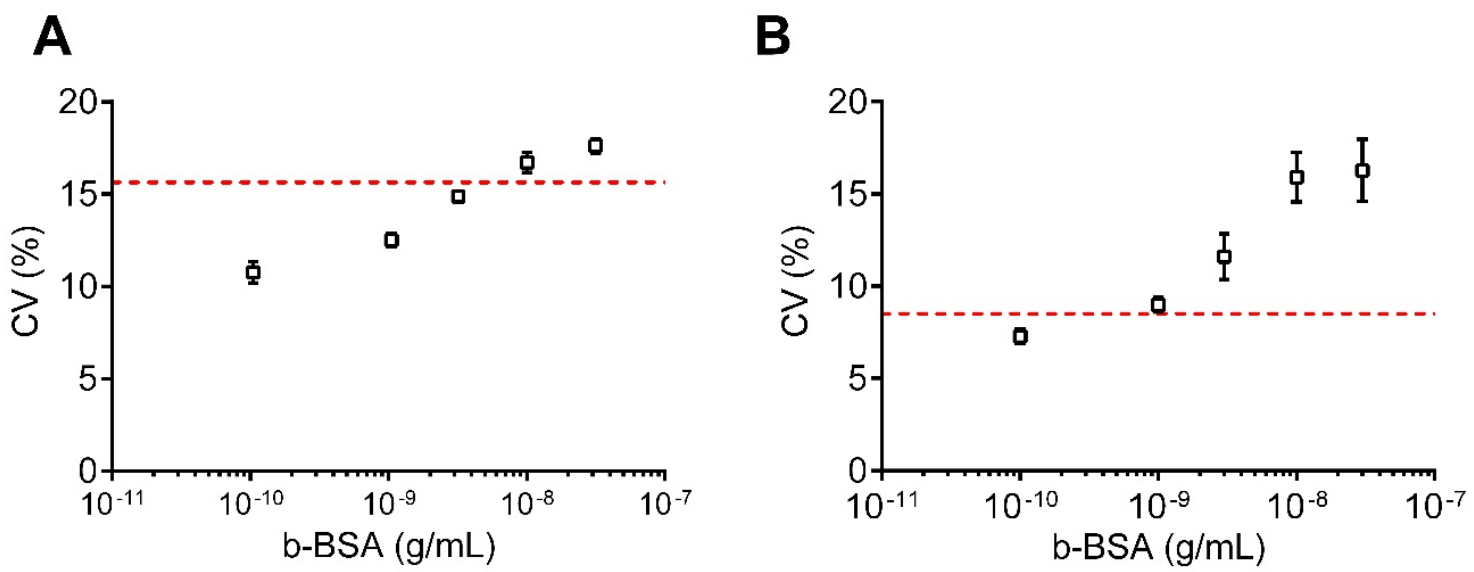

Figure S15 Distribution analysis of FBS samples diluted with (a) PBST and (b) PBSP after outliers were removed with ROUT analysis for $\mathrm{Q}=1 \%$. Data are presented as mean of three replicates with error bars ( \pm SD). Dashed lines represent LOD signal (LOD is calculated as mean CV (\%) of reference plus three times of $\pm \mathrm{SD}$
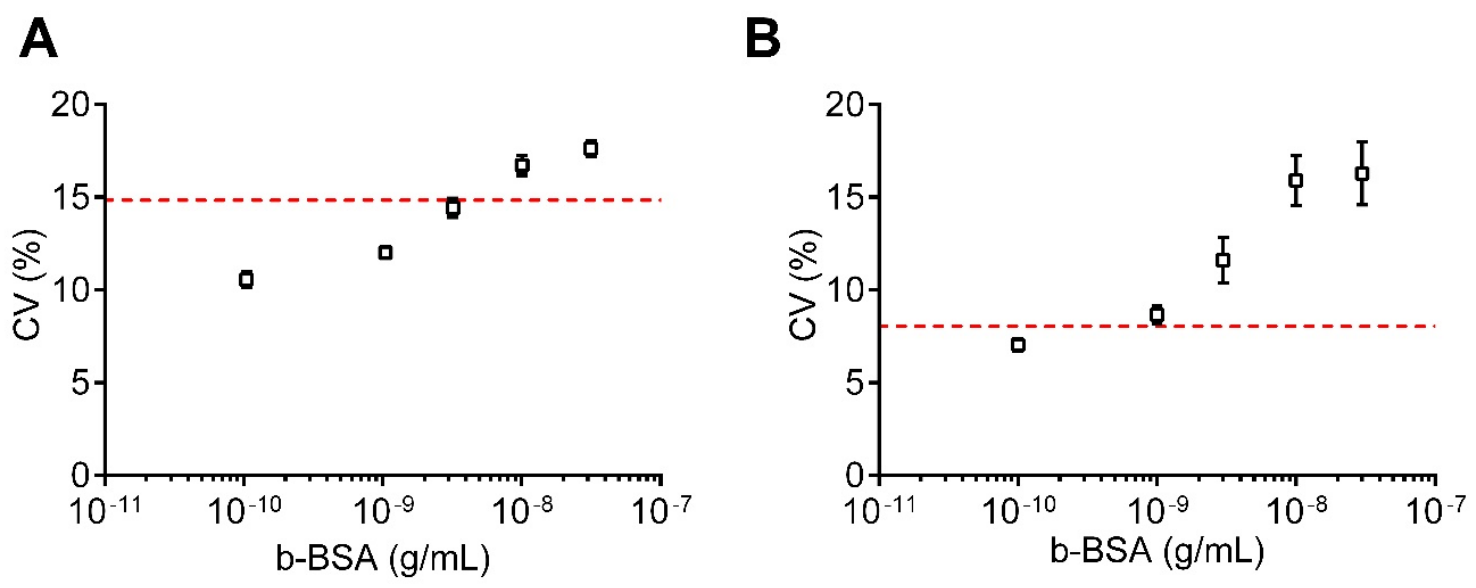

Figure S16 Distribution analysis of FBS samples diluted with (a) PBST and (b) PBSP after outliers were removed with ROUT analysis for $\mathrm{Q}=2 \%$. Data are presented as mean of three replicates with error bars $( \pm \mathrm{SD})$. Dashed lines represent LOD signal (LOD is calculated as mean CV $(\%)$ of reference plus three times of $\pm \mathrm{SD}$ ). 

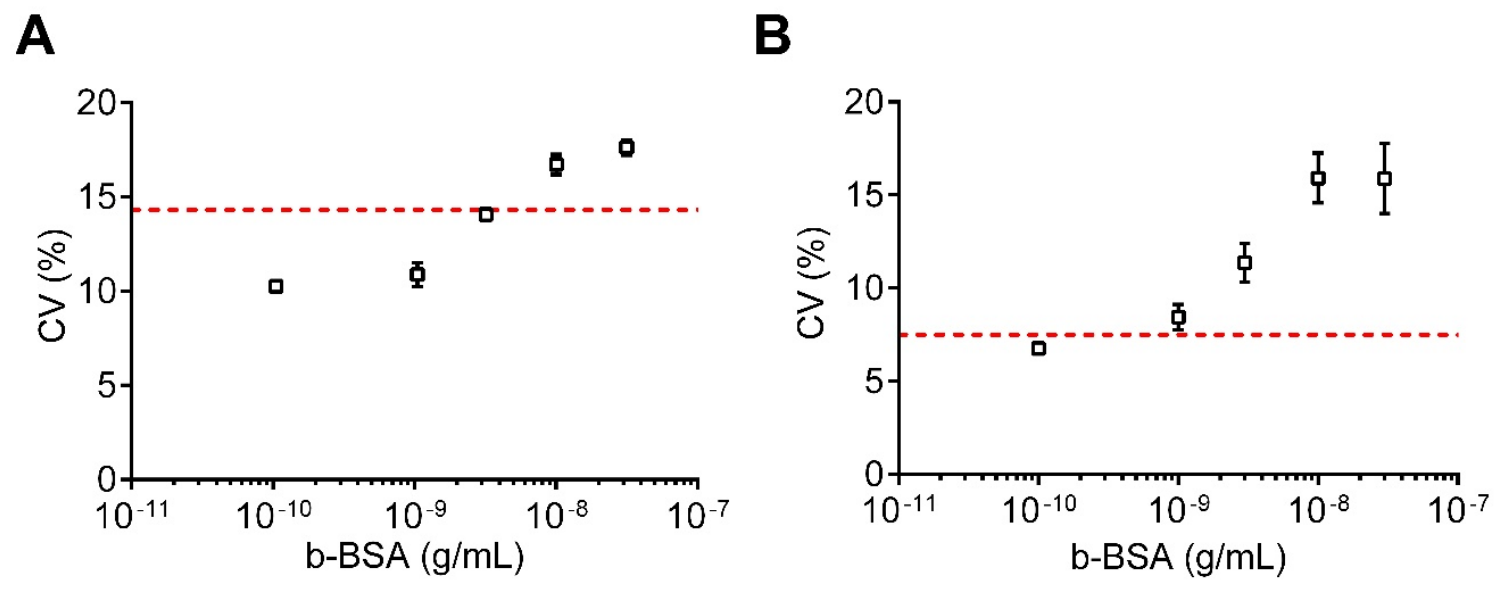

Figure S17 Distribution analysis of FBS samples diluted with (a) PBST and (b) PBSP after outliers were removed with ROUT analysis for $\mathrm{Q}=5 \%$. Data are presented as mean of three replicates with error bars ( \pm SD). Dashed lines represent LOD signal (LOD is calculated as mean CV (\%) of reference plus three times of $\pm \mathrm{SD}$ ).
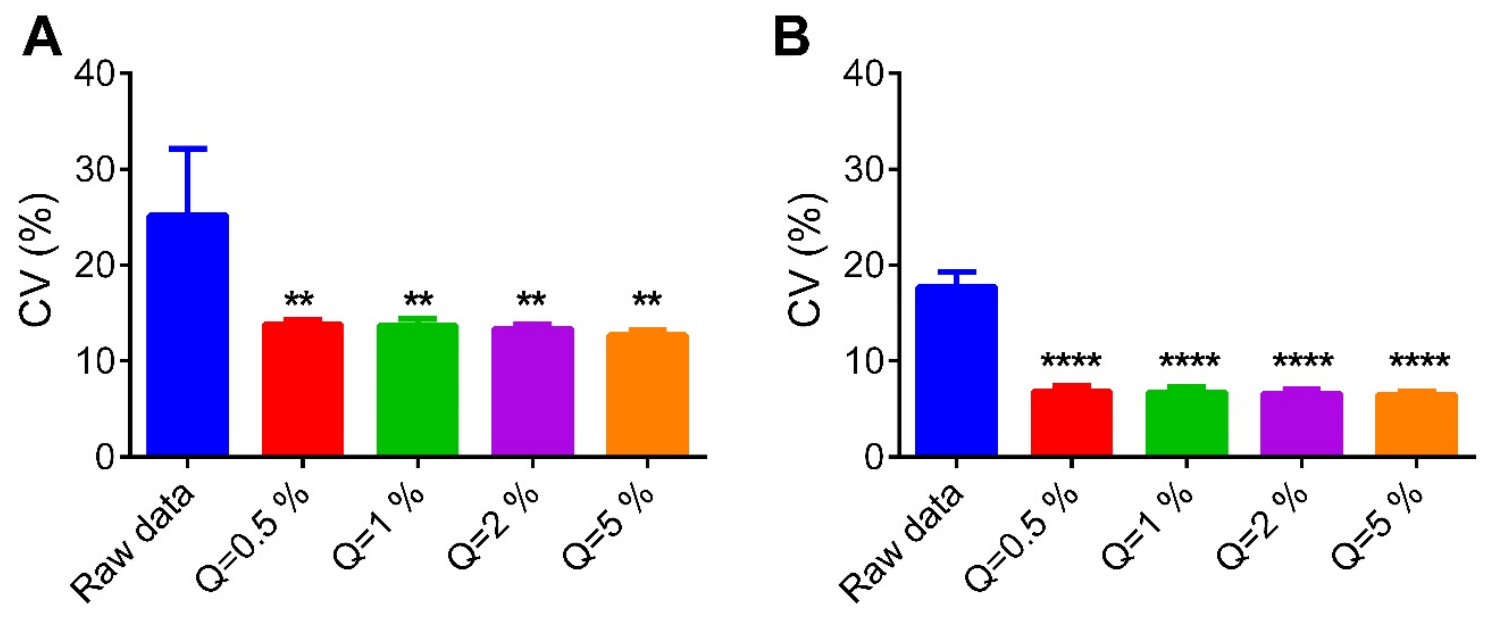

Figure S18 Distribution analysis of reference tests (i.e., $0 \mathrm{~g} / \mathrm{mL}$ b-BSA) in serum samples diluted with (A) PBST and (B) PBSP before and after removing outliers with ROUT for different Q. Data are presented as mean of three replicates with error bars $( \pm \mathrm{SD})$. Data were compared to the raw data of $0 \mathrm{ng} / \mathrm{mL}$ b-BSA using a one-way ANOVA for both PBST and PBSP. ** and **** represent $P<0.01$ and $P<0.0001$, respectively $(n=3)$. Increased in $Q$ value $(Q \geq 0.5 \%)$ did not affect $C V$ values of reference tests. Since high $Q$ values $(>1 \%)$ have a risk to identify a point falsely as an outlier, ${ }^{6}$ we used $1 \% \mathrm{Q}$ value for protein analysis. 


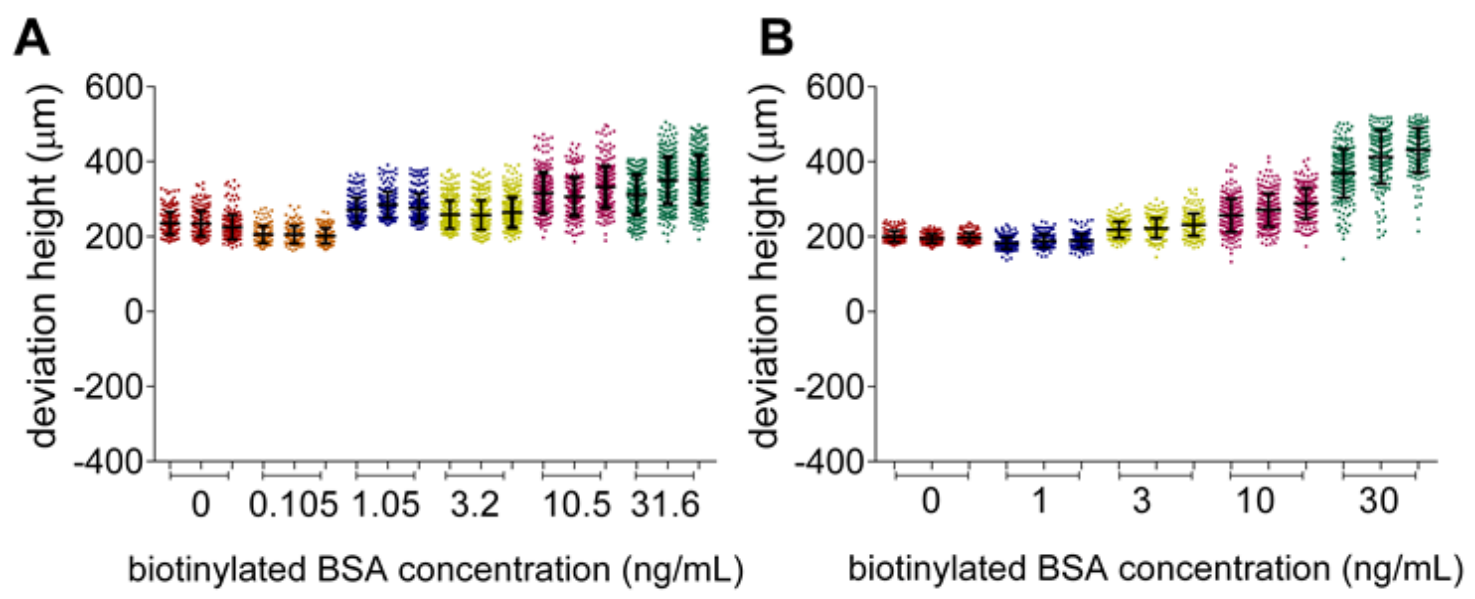

Figure S19 The deviation height of each microsphere under various b-BSA concentrations when the outliers are removed using ROUT method with $\mathrm{Q}=1 \%$ for PBST (A) and PBSP (B) dilution, respectively.
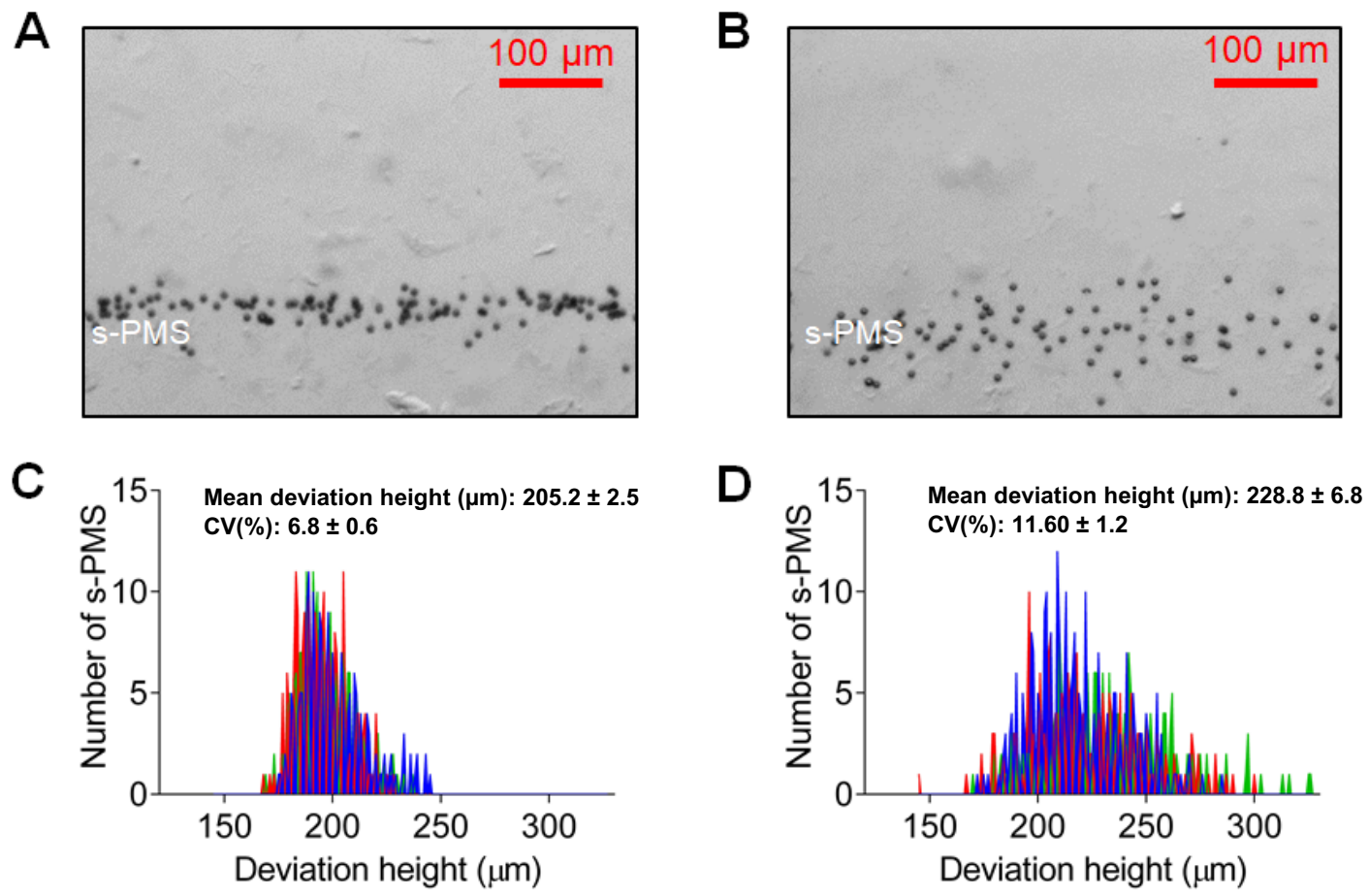

Figure S20 Levitation profile of s-PMS in the absence and presence of b-BSA in serum sample diluted with PBSP under $30 \mathrm{mM} \mathrm{Gd}^{3+}$ concentration. Micrographs of s-PMS (A) without b-BSA and (B) with b-BSA (3 $\mathrm{ng} / \mathrm{mL})$. Distribution analysis of s-PMS (C) without b-BSA and (D) with b-BSA. In the presence of b-BSA, CV was increased 1.7-fold and, on the other hand, the average deviation height was increased 1.1-fold compared to no b-BSA case. Experimental data in C and $\mathrm{D}$ were presented as blue, red, green colors for three replicates with statistically removed outliers $(\mathrm{Q}=1 \%)$. 
A

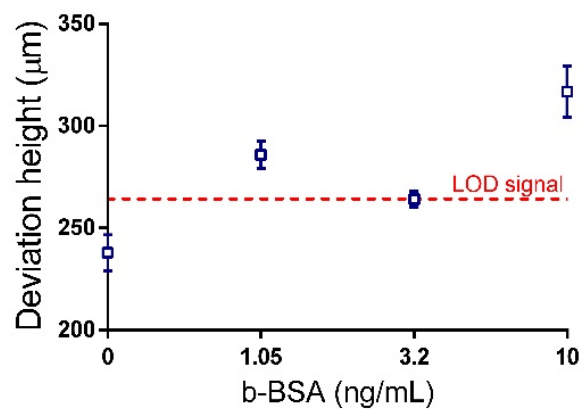

I \begin{tabular}{|c|c|c|c|c|c|}
\hline $\begin{array}{c}\text { b-BSA } \\
(\mathbf{n g} / \mathbf{m L})\end{array}$ & $\begin{array}{c}\text { Average } \\
\text { height in } \\
\text { Test 1 }(\boldsymbol{\mu m})\end{array}$ & $\begin{array}{c}\text { Average } \\
\text { height in } \\
\text { Test 2 }(\boldsymbol{\mu m})\end{array}$ & $\begin{array}{c}\text { Average } \\
\text { height in } \\
\text { Test } \mathbf{3}(\boldsymbol{\mu m})\end{array}$ & $\begin{array}{c}\text { Average } \\
\text { height in all } \\
\text { tests }(\boldsymbol{\mu m})\end{array}$ & $\begin{array}{c}\mathbf{\pm} \text { SD } \\
(\boldsymbol{\mu m})\end{array}$ \\
\hline 0 & 243.9 & 244.3 & 225.5 & 237.9 & 8.8 \\
\hline 1.05 & 278.4 & 294.5 & 285.0 & 286.0 & 6.6 \\
\hline 3.2 & 264.5 & 259.1 & 268.7 & 264.1 & 3.9 \\
\hline 10 & 315.9 & 302.1 & 332.4 & 316.8 & 12.4 \\
\hline
\end{tabular}

B

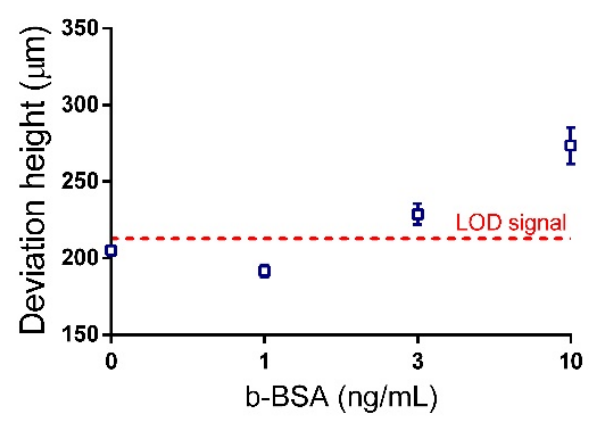

\begin{tabular}{|c|c|c|c|c|c|}
\hline $\begin{array}{c}\text { b-BSA } \\
(\mathbf{n g} / \mathrm{mL})\end{array}$ & $\begin{array}{c}\text { Average } \\
\text { height in } \\
\text { Test 1 }(\boldsymbol{\mu \mathrm { m }})\end{array}$ & $\begin{array}{c}\text { Average } \\
\text { height in } \\
\text { Test 2 }(\boldsymbol{\mu m})\end{array}$ & $\begin{array}{c}\text { Average } \\
\text { height in } \\
\text { Test 3 }(\boldsymbol{\mu m})\end{array}$ & $\begin{array}{c}\text { Average } \\
\text { height in all } \\
\text { tests }(\boldsymbol{\mu m})\end{array}$ & $\begin{array}{c}\mathbf{\pm} \text { SD } \\
(\boldsymbol{\mu m})\end{array}$ \\
\hline 0 & 208.7 & 203.2 & 203.6 & 205.2 & 2.5 \\
\hline 1 & 186.2 & 194.7 & 194.6 & 191.8 & 4.0 \\
\hline 3 & 221.2 & 227.5 & 237.7 & 228.8 & 6.8 \\
\hline 10 & 260.3 & 270.9 & 289.3 & 273.5 & 12.0 \\
\hline
\end{tabular}

C

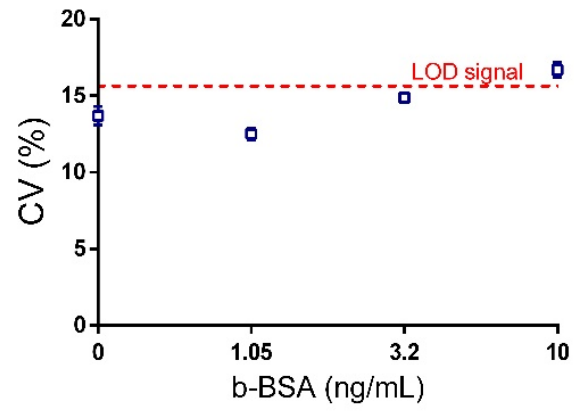

\begin{tabular}{|c|c|c|c|c|c|}
\hline $\begin{array}{c}\text { b-BSA } \\
(\mathbf{n g} / \mathrm{mL})\end{array}$ & $\begin{array}{c}\text { Average } \\
\text { height in } \\
\text { Test } 1(\boldsymbol{\mu m})\end{array}$ & $\begin{array}{c}\text { Average } \\
\text { height in } \\
\text { Test 2 }(\boldsymbol{\mu m})\end{array}$ & $\begin{array}{c}\text { Average } \\
\text { height in } \\
\text { Test } \mathbf{3}(\boldsymbol{\mu \mathrm { m }})\end{array}$ & $\begin{array}{c}\text { Average } \\
\text { height in all } \\
\text { tests }(\boldsymbol{\mu m})\end{array}$ & $\begin{array}{c}\mathbf{\pm} \text { SD } \\
(\boldsymbol{\mu m})\end{array}$ \\
\hline 0 & 12.9 & 14.3 & 14.0 & 13.7 & 0.6 \\
\hline 1.05 & 12.4 & 12.1 & 13.0 & 12.5 & 0.4 \\
\hline 3.2 & 14.5 & 15.2 & 15.0 & 14.9 & 0.3 \\
\hline 10 & 17.29 & 16.86 & 16 & 16.7 & 0.5 \\
\hline
\end{tabular}

D

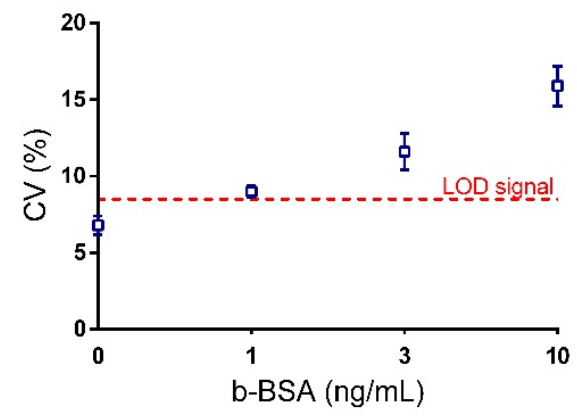

\begin{tabular}{|c|c|c|c|c|c|}
\hline $\begin{array}{c}\text { b-BSA } \\
(\mathbf{n g} / \mathbf{m L})\end{array}$ & $\begin{array}{c}\text { Average } \\
\text { height in } \\
\text { Test } \mathbf{1}(\boldsymbol{\mu m})\end{array}$ & $\begin{array}{c}\text { Average } \\
\text { height in } \\
\text { Test } \mathbf{2}(\boldsymbol{\mu} \mathrm{m})\end{array}$ & $\begin{array}{c}\text { Average } \\
\text { height in } \\
\text { Test } \mathbf{3}(\boldsymbol{\mu m})\end{array}$ & $\begin{array}{c}\text { Average } \\
\text { height in all } \\
\text { tests }(\boldsymbol{\mu m})\end{array}$ & $\begin{array}{c}\mathbf{\mathbf { m }} \mathbf{\mathrm { SD }} \\
(\boldsymbol{\mu} \mathbf{m})\end{array}$ \\
\hline 0 & 7.5 & 6.1 & 6.7 & 6.8 & 0.6 \\
\hline 1 & 8.4 & 9.4 & 9.2 & 9.0 & 0.4 \\
\hline 3 & 9.9 & 12.0 & 12.9 & 11.6 & 1.2 \\
\hline 10 & 17.3 & 16.3 & 14.1 & 15.9 & 1.3 \\
\hline
\end{tabular}

Figure S21 Experimental data conducted in FBS samples for different b-BSA concentration using $30 \mathrm{mM} \mathrm{Gd}^{3+}$. Deviation height and CV (\%) analyses for the samples diluted with (A, C) PBST and (B, D) PBSP, respectively. 


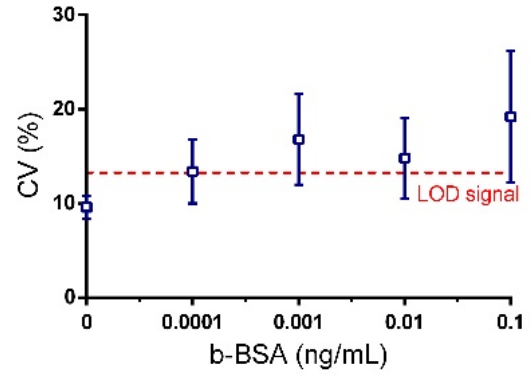

\begin{tabular}{|c|c|c|c|c|c|}
\hline $\begin{array}{c}\text { b-BSA } \\
(\mathbf{n g} / \mathbf{m L})\end{array}$ & $\begin{array}{c}\text { Average } \\
\text { height in } \\
\text { Test 1 }(\boldsymbol{\mu m})\end{array}$ & $\begin{array}{c}\text { Average } \\
\text { height in } \\
\text { Test } \mathbf{2}(\boldsymbol{\mu m})\end{array}$ & $\begin{array}{c}\text { Average } \\
\text { height in } \\
\text { Test } \mathbf{3}(\boldsymbol{\mu m})\end{array}$ & $\begin{array}{c}\text { Average } \\
\text { height in all } \\
\text { tests }(\boldsymbol{\mu m})\end{array}$ & $\begin{array}{c}\mathbf{\pm} \text { SD } \\
(\boldsymbol{\mu} \mathbf{m})\end{array}$ \\
\hline 0 & 9.7 & 8.1 & 11.0 & 9.6 & 1.2 \\
\hline 0.0001 & 18.3 & 11.2 & 10.8 & 13.4 & 3.4 \\
\hline 0.001 & 17.1 & 22.5 & 10.8 & 16.8 & 4.8 \\
\hline 0.01 & 19.6 & 15.7 & 9.1 & 14.8 & 4.3 \\
\hline 0.1 & 18.7 & 10.9 & 28.0 & 19.2 & 7.0 \\
\hline
\end{tabular}

Figure S22 Experimental data conducted in FBS samples for different b-BSA concentration using $30 \mathrm{mM} \mathrm{Gd}^{3+}$ and 1:10 diluted s-PMS. The FBS samples were diluted with PBSP.
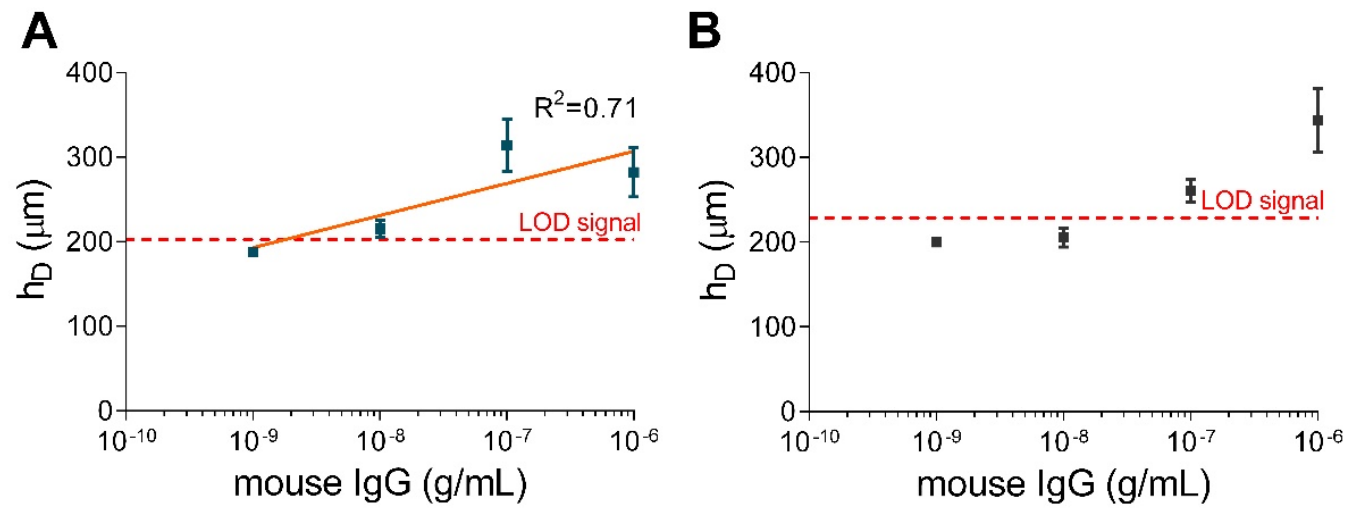

Figure S23 Deviation height analysis of the anti-mouse IgG microspheres for different concentrations of mouse IgG spiked in (A) PBS and (B) FBS. Data collected using $30 \mathrm{mM} \mathrm{Gd}^{3+}$ based levitation medium are shown as mean of three replicates with error bars $( \pm \mathrm{SD})$. A linear fit to the data with a coefficient of determination $\left(\mathrm{R}^{2}\right)$ is shown as a solid line. The LOD concentrations based on deviation height analysis were $1.8 \mathrm{ng} / \mathrm{mL}$ and $>10 \mathrm{ng} / \mathrm{mL}$ for buffer and serum, respectively. 
Table S2. Summary of the magnetic levitation-based protein detection strategies

\begin{tabular}{|c|c|c|c|c|c|c|}
\hline $\begin{array}{c}\text { Target } \\
\text { Molecule }\end{array}$ & Sample & $\begin{array}{l}\text { Sample } \\
\text { Volume }\end{array}$ & Assay time & LOD & $\begin{array}{l}\text { Working } \\
\text { Principle } \\
\end{array}$ & Ref. \\
\hline IL-6 & PBS & $\begin{array}{c}\text { Not } \\
\text { reported }\end{array}$ & $\begin{array}{l}\text { Incubation } \\
\text { (40 min) + } \\
\text { Levitation } \\
\text { (Not } \\
\text { Reported) }\end{array}$ & $10 \mathrm{pg} / \mathrm{mL}$ & $\begin{array}{l}\text { Density } \\
\text { change }\end{array}$ & 7 \\
\hline Neomycin & Milk & $25 \mu \mathrm{L}$ & \multirow[t]{2}{*}{$<1 \mathrm{~h}$} & $250 \mathrm{ppb}$ & \multirow[t]{2}{*}{$\begin{array}{l}\text { Density } \\
\text { change }\end{array}$} & \multirow[t]{2}{*}{8} \\
\hline $\begin{array}{c}\text { Syphilis and } \\
\text { hepatitis C } \\
\text { antibodies }\end{array}$ & Serum & $100 \mu \mathrm{L}$ & & $\begin{array}{l}\text { Qualitative } \\
(+/- \\
\text { response) }\end{array}$ & & \\
\hline $\begin{array}{c}\text { Bovine carbonic } \\
\text { anhydrase } \\
\text { (BCA) }\end{array}$ & PBS/Blood & $20 \mu \mathrm{L}$ & $3-24 \mathrm{~h}$ & $\begin{array}{c}300-600 \\
\mathrm{nM}\end{array}$ & $\begin{array}{l}\text { Density } \\
\text { change }\end{array}$ & 9 \\
\hline $\begin{array}{c}\text { Anti-T. cruzi } \\
\text { antibodies }\end{array}$ & Blood & $<30 \mu \mathrm{L}$ & $\sim 55 \mathrm{~min}$ & $5 \mu \mathrm{g} / \mathrm{mL}$ & $\begin{array}{l}\text { Density } \\
\text { change }\end{array}$ & 10 \\
\hline $\begin{array}{l}\text { Biotinylated } \\
\text { bovine serum } \\
\text { albumin } \\
\end{array}$ & FBS & \multirow[t]{2}{*}{$200 \mu \mathrm{L}$} & \multirow{2}{*}{$\begin{array}{c}\text { Incubation } \\
(\sim 50 \text { min })+ \\
\text { Levitation } \\
(30 \text { min })\end{array}$} & $\begin{array}{c}110 \mathrm{fg} / \mathrm{mL} \\
(1.6 \mathrm{fM})\end{array}$ & \multirow[t]{2}{*}{$\begin{array}{c}\text { Magnetic } \\
\text { susceptibility } \\
\text { change }\end{array}$} & \multirow[t]{2}{*}{$\begin{array}{l}\text { Our } \\
\text { Study }\end{array}$} \\
\hline $\begin{array}{c}\text { Mouse } \\
\text { immunoglobulin } \\
\mathrm{G}\end{array}$ & PBS/FBS & & & $\begin{array}{c}1.5 \mathrm{ng} / \mathrm{mL} \\
(10 \mathrm{pM}) \\
\text { (in PBS)/ } \\
>10 \mathrm{ng} / \mathrm{mL} \\
\text { (in FBS) }\end{array}$ & & \\
\hline
\end{tabular}
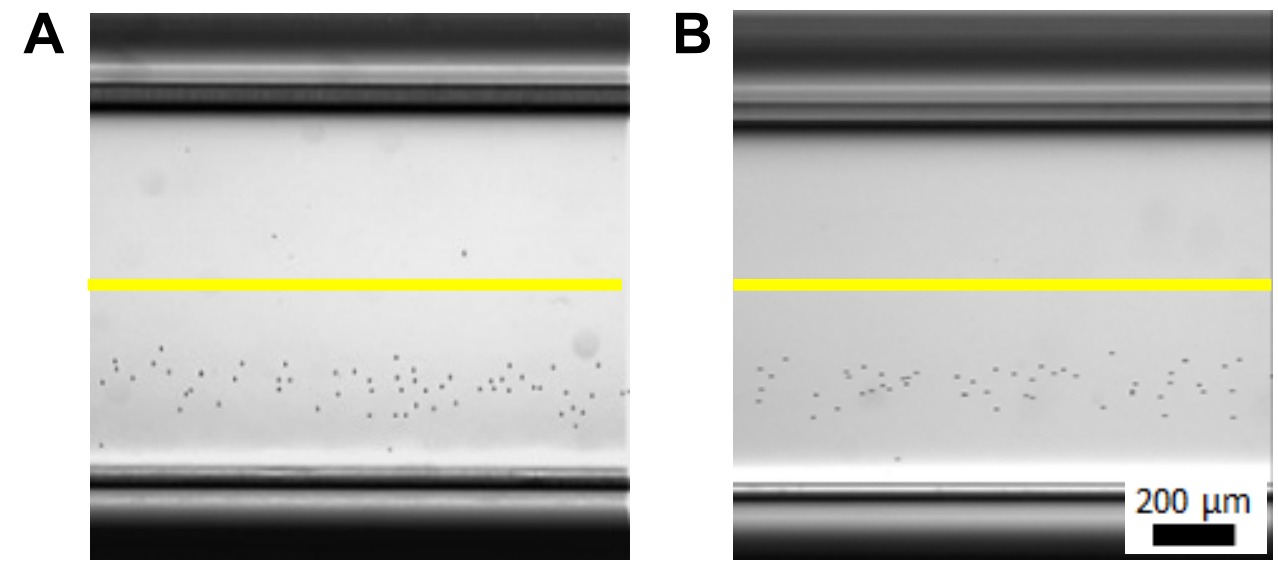

Figure S24 Comparison of deviation heights of s-PMS in the presence of $1 \mathrm{ng} / \mathrm{mL}$ b-BSA under two different incubation protocols using $30 \mathrm{mM} \mathrm{Gd}^{3+}$ in PBS. The micrographs of the s-PMS with the protocol (A) not including centrifugation before the addition of s-MNP and (B) including centrifugation before the addition of s-MNP. Yellow lines: centerline. 


\section{References}

(1) Durmus, N. G.; Tekin, H. C.; Guven, S.; Sridhar, K.; Arslan Yildiz, A.; Calibasi, G.; Ghiran, I.; Davis, R. W.; Steinmetz, L. M.; Demirci, U., Magnetic levitation of single cells. Proceedings of the National Academy of Sciences 2015, 1-8.

(2) Zhang, H.; Moore, L. R.; Zborowski, M.; Williams, P. S.; Margel, S.; Chalmers, J. J., Establishment and implications of a characterization method for magnetic nanoparticle using cell tracking velocimetry and magnetic susceptibility modified solutions. Analyst 2005, 130 (4), 51427.

(3) Gaster, R. S.; Hall, D. A.; Nielsen, C. H.; Osterfeld, S. J.; Yu, H.; Mach, K. E.; Wilson, R. J.; Murmann, B.; Liao, J. C.; Gambhir, S. S.; Wang, S. X., Matrix-insensitive protein assays push the limits of biosensors in medicine. Nature Medicine 2009, 15 (11), 1327-1332

(4) Rissin, D. M.; Kan, C. W.; Campbell, T. G.; Howes, S. C.; Fournier, D. R.; Song, L.; Piech, T.; Patel, P. P.; Chang, L.; Rivnak, A. J.; Ferrell, E. P.; Randall, J. D.; Provuncher, G. K.; Walt, D. R.; Duffy, D. C., Single-molecule enzyme-linked immunosorbent assay detects serum proteins at subfemtomolar concentrations. Nature Biotechnology 2010, 28, 595.

(5) Tekin, H. C.; Cornaglia, M.; Gijs, M. A. M., Attomolar protein detection using a magnetic bead surface coverage assay. Lab on a chip 2013, 13 (6), 1053-1059.

(6) Motulsky, H. J.; Brown, R. E., Detecting outliers when fitting data with nonlinear regression a new method based on robust nonlinear regression and the false discovery rate. BMC Bioinformatics 2006, 7 (1), 123.

(7) Andersen, M. S.; Howard, E.; Lu, S.; Richard, M.; Gregory, M.; Ogembo, G.; Mazor, O.; Gorelik, P.; Shapiro, N. I.; Sharda, A. V.; Ghiran, I., Detection of membrane-bound and soluble antigens by magnetic levitation. Lab on a Chip 2017, 17 (20), 3462-3473.

(8) Subramaniam, A. B.; Gonidec, M.; Shapiro, N. D.; Kresse, K. M.; Whitesides, G. M., Metalamplified Density Assays, (MADAs), including a Density-Linked Immunosorbent Assay (DeLISA). Lab on a chip 2015, 15 (4), 1009-1022.

(9) Shapiro, N. D.; Mirica, K. A.; Soh, S.; Phillips, S. T.; Taran, O.; Mace, C. R.; Shevkoplyas, S. S.; Whitesides, G. M., Measuring binding of protein to gel-bound ligands using magnetic levitation. Journal of the American Chemical Society 2012, 134 (12), 5637-5646.

(10) Castro, B.; de Medeiros, M. S.; Sadri, B.; Martinez, R. V., Portable and power-free serodiagnosis of Chagas disease using magnetic levitating microbeads. Analyst 2018, 143 (18), 4379-4386. 